\title{
Understanding variations in catastrophic health expenditure, its underlying determinants and impoverishment in Sub- Saharan African countries: a scoping review
}

Purity Njagi ${ }^{1 *}$ (D) Jelena Arsenijevic ${ }^{2,3}$ and Wim Groot ${ }^{2}$

\begin{abstract}
Background: To assess the financial burden due to out of pocket (OOP) payments, two mutually exclusive approaches have been used: catastrophic health expenditure (CHE) and impoverishment. Sub-Saharan African (SSA) countries primarily rely on OOP and are thus challenged with providing financial protection to the populations. To understand the variations in $\mathrm{CHE}$ and impoverishment in SSA, and the underlying determinants of $\mathrm{CHE}$, a scoping review of the existing evidence was conducted.

Methods: This review is guided by Arksey and O'Malley scoping review framework. A search was conducted in several databases including PubMed, EBSCO (EconLit, Psycholnfo, CINAHL), Web of Science, Jstor and virtual libraries of the World Health Organizations (WHO) and the World Bank. The primary outcome of interest was catastrophic health expenditure/impoverishment, while the secondary outcome was the associated risk factors.

Results: Thirty-four (34) studies that met the inclusion criteria were fully assessed. CHE was higher amongst West African countries and amongst patients receiving treatment for HIV/ART, TB, malaria and chronic illnesses. Risk factors associated with CHE included household economic status, type of health provider, socio-demographic characteristics of household members, type of illness, social insurance schemes, geographical location and household size/ composition. The proportion of households that are impoverished has increased over time across countries and also within the countries.

Conclusion: This review demonstrated that CHE/impoverishment is pervasive in SSA, and the magnitude varies across and within countries and over time. Socio-economic factors are seen to drive CHE with the poor being the most affected, and they vary across countries. This calls for intensifying health policies and financing structures in SSA, to provide equitable access to all populations especially the most poor and vulnerable. There is a need to innovate and draw lessons from the 'informal' social networks/schemes as they are reported to be more effective in cushioning the financial burden.
\end{abstract}

Keywords: Catastrophic health expenditure, Impoverishment, Out of pocket payments, Sub-Saharan Africa, Scoping review

\footnotetext{
* Correspondence: p.njagi@student.maastrichtuniversity.nl;

puritynjagih@gmail.com

${ }^{1}$ United Nations University - Maastricht Economic and social Research

institute on Innovation and Technology(UNU-MERIT), Maastricht University,

Maastricht, The Netherlands

Full list of author information is available at the end of the article
}

(c) The Author(s). 2018 Open Access This article is distributed under the terms of the Creative Commons Attribution 4.0 International License (http://creativecommons.org/licenses/by/4.0/), which permits unrestricted use, distribution, and

reproduction in any medium, provided you give appropriate credit to the original author(s) and the source, provide a link to the Creative Commons license, and indicate if changes were made. The Creative Commons Public Domain Dedication waiver (http://creativecommons.org/publicdomain/zero/1.0/) applies to the data made available in this article, unless otherwise stated. 


\section{Background}

Financial barriers are a key limitation to access health services in low- and middle-income countries (LMICs) $[1,2]$. Financial barriers are usually related to out of pocket patient payments and their impact on household budget [3]. Two main approaches are used to assess the financial barriers: catastrophic health expenditure that occurs when out of pocket (OOP) payment equals or exceeds a pre-specified threshold of household expenditure or capacity to pay $[4,5]$, and impoverishment that occurs when the average household consumption after health care payment is below the pre-specified international or national poverty line [6].

The incidence of catastrophic payments is reported to be higher in low-income countries that rely on OOP, and lower in countries that have some prepayment mechanisms $[5,7]$. While impoverishment is usually reported in LMICs, catastrophic payments also exist in high-income countries, and are slightly concentrated amongst the less well-off $[5,8]$. This trend is also observed in African countries. Studies in Sub-Saharan African (SSA) countries have shown that inequities in access exist as a result of income differences and the level of OOP within the country. The proportion of households facing catastrophic health care payments has been shown to vary widely between countries [9-11].The World Health organization (WHO) argues that when people suffer financial hardship due to OOP, it is impossible to get closer to universal health coverage (UHC) due to the high risk of catastrophe and impoverishment [12]. Moreover, UHC aims to ensure that health care benefits are distributed on the basis of need for care and not on ability to pay [13]. The burden of OOP payments has encouraged SSA countries to use different financial arrangements to prevent catastrophic payments [14]. One of them is introduction of insurance systems with universal population coverage [15], and another is removal of user fees. There is also a trend by governments to move out of the OOP payments that are considered to impoverish those who are already poor [16]. Given the over reliance on OOP payments in most of SSA countries, and with most countries having inadequate social insurance schemes, there is a strong need to evaluate systematically the existing evidence on financial inequity in access to healthcare. Furthermore, the effectiveness of the health financing system is seen through protecting people against the risk of becoming poor, while enabling them to make use of services [17]. In addition, WHO underscores health care financing as one of the crucial components of the broader efforts to ensure social protections [12].

Systematic reviews synthesise evidence given their clearly formulated structure and the methodological rigour [18]. Several studies have reviewed the variations in health indicators in SSA; however, most of these have focused on health status, service coverage and utilisation indicators like mortality rates and incidence/prevalence of diseases [19, 20]. There have been few reviews that focus on unequal access to health care due to financial barriers [21]. Lack of systematic reviews in this area is perceived by policy makers as a limitation in decision making and developing new strategies [22]. While there are several systematic reviews on catastrophic payments and impoverishment in LMICs [23, 24], very few have incorporated literature from SSA, and those that have done so have included only one or two countries from the SSA region $[5,25]$. A few other reviews that have been conducted are disease specific [26-28] and do not review the CHE risk factors. To our knowledge, there is currently no systematic and/or scoping review that examines the scale and variations of $\mathrm{CHE}$ and impoverishment across SSA countries. To understand the scope and nature of the studies conducted in SSA, we apply a scoping review approach. Scoping reviews are considered appropriate in that they not only bring together the available evidence but also provide broader synthesis of the evidence [29]. The aim of this study is to provide an overview of the magnitude and distribution of catastrophic health expenditure and impoverishment due to OOP for healthcare across SSA countries. Furthermore, we also look into the determinants of CHE that have been identified across SSA countries. This will not only highlight the scale of the problem but also identify any gaps that could potentially strengthen future research in $\mathrm{CHE} /$ impoverishment in SSA countries. The findings will help in developing effective health policies [30], that are more targeted, prioritise the vulnerable populations and address key risk factors. In addition, the findings could help to inform strategic health financing priorities of SSA member states by development partners/regional blocs like the African union (AU), WHO and World bank amongst others that invest in health initiatives in the region.

This study therefore responds to the research question: what variations exist in the distribution of $\mathrm{CHE}$ and/or impoverishment and the associated risk factors across SSA countries? The paper continues with the methods section (searching strategy and study selection) followed by the results section and discussion with conclusions.

\section{Methods}

This scoping review is based on the framework proposed by Arksey and O'Malley [31] and incorporates recommendations proposed by Levac [32]. In addition, the Preferred Reporting Items for Systematic Reviews and Meta-Analyses [PRISMA] (See Additional file 1) that provides key items considered to be essential and minimum components of a systematic review or meta-analysis protocol 
[33], was applied to guide the screening and eligibility of the studies.

\section{Search strategy and inclusion criteria Inclusion and exclusion criteria}

This review included studies that focused on all population groups including vulnerable groups like people living with disability, the elderly or children in both rural and urban settings. Studies with the primary aim of assessing catastrophic health expenditure and household impoverishment due to out of pocket payments in health care were included. We particularly look at the incidence of CHE and impoverishment, defined as the proportion of households whose out of pocket spending on health care is catastrophic or drives them into poverty. The intensity of CHE or impoverishment defined as the extent to which the household expenditure exceeds the set threshold or poverty line was also included. In addition, we reviewed studies that assessed the risk factors associated with the observed levels of incidence in catastrophic health expenditure.

We considered studies that assessed CHE and/or impoverishment due to seeking any type of health care service including HIV/AIDS, TB, chronic illnesses, malaria and maternal health services. The review was restricted to studies undertaken in any of the 45 Sub-Saharan African countries with coverage of either part of the country, the entire country or multiple countries. Articles were considered for inclusion if they were observational studies including cross-sectional studies, case-control, comparative or longitudinal studies. We excluded articles that were discussion papers or general literature review on CHE or impoverishment, qualitative studies that discussed $\mathrm{CHE}$ and those that addressed methodological issues and global macro analysis on CHE. These articles do not provide outcome measures that are relevant for our study such as the incidence or intensity of CHE.

\section{Search strategy}

We commenced with a general search on Google Scholar, and then searched in several databases namely PubMed, EBSCO (EconLit, PsychoInfo, CINAHL), Web of Science and Jstor. We also searched through the grey literature of relevant organisations virtual libraries such as World Health Organization (WHO) and the World Bank. In addition, a forward search of authors mentioned in selected articles was also conducted. The search terms included 'Catastrophic', 'Impoverishment', 'Financial burden,' 'Economic burden', and under PubMed search, we included the MESH terms for health expenditure, health care costs and Sub-Saharan African countries. These words were used for all the other database searches. The detailed search chain for PubMed is provided in Additional file 2. Only studies published in
English language in the last 10 years (2006-May 2017) were included for review.

\section{Data extraction and analysis}

The main reviewer extracted and analysed data from all articles in consultation with the other authors. Information extracted from the publications included context of the study (country and year of publication), characteristics of the included population, methodology (design of the study, data source, sample size, type of analysis), primary (incidence and intensity of $\mathrm{CHE} / \mathrm{Impoverishment)}$ and secondary outcomes (determinants of CHE). Studies were grouped by the outcome measures. As a primary outcome measure, we use the incidence and intensity of catastrophic expenditure and impoverishment. To measure the impact of OOP on household expenditure; varying thresholds were applied which varied from 5 to $40 \%$ as a ratio of household expenditure or non-food expenditure. Information on the determinants of CHE and impoverishment were reported as secondary outcomes. Articles were also classified according to four major SSA regions (West Africa, East Africa, South Africa and Central Africa).

\section{Quality and risk of bias assessment}

Although quality assessments are not a standard requirement in scoping reviews, it has been argued that the lack of it could minimise the rigour and challenge the interpretation of the findings [32]. In light of this, quality assessment of the studies was conducted by the main reviewer in consultation with the other authors. The Quality Assessment Tool for Observational Cohort and Cross-Sectional Studies was applied to evaluate the quality of the studies included. The tool is recommended by the NIH and has been used in several systematic reviews to assess internal validity [34] (See Additional file 3). For each question, studies are given scores on a Yes (1) or No (0), and others which include CD, cannot determine; NA, not applicable and NR, not reported.

All the studies included in this review were assessed for quality using the criteria that fits the respective studies, and for those studies which some elements of the criteria did not apply, these were marked as not applicable. The assessment of exposure measures was only done for those studies that focused on the risk factors associated with CHE. On average, all the studies met the quality criteria, apart from six studies $[11,13,24,29,31$, 34] that assessed exposure factors that vary by levels that did not examine the different levels of exposure. In addition, one multi-country study [18] did not report on the sample size; thus, the three criteria related to the study sample could not be determined. Figure 1 shows the ratio of studies that met the respective criteria. 


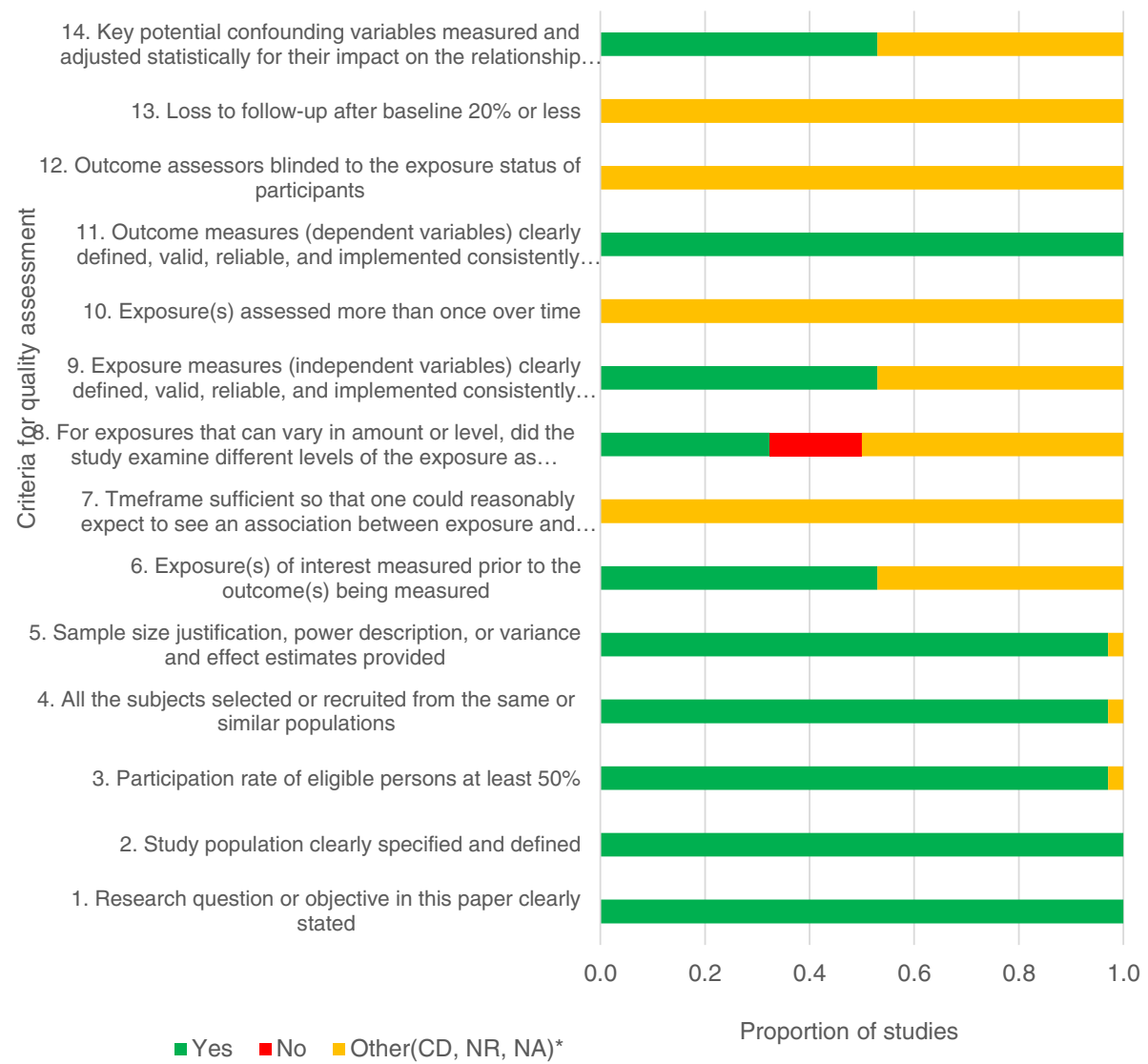

Fig. 1 Quality assessment of included studies. The figure represents a summary of the quality assessment scores as per the assessment criteria/checklist

\section{Results}

\section{Study selection}

The initial search identified a total of 512 articles from the main journals and another 33 articles from the additional databases of the WHO and the World Bank. Once duplicates were removed, a total of 501 articles remained. Using title and abstracts, one reviewer screened all the identified articles based on an agreed inclusion criteria with the other two authors. A total of 445 articles were excluded largely due to being non-SSA specific, or for having a general focus on national health expenditure instead of $\mathrm{CHE}$ and impoverishment. A total of 56 articles remained that were fully assessed for eligibility; a second reviewer went through these selected articles and provided recommendations. The three reviewers had concurrence to include 34 articles in the final review analysis. The main reason for dropping 22 studies included the fact that the outcome was level of OOP and not the proportion that was catastrophic. Also, these articles do not provide information that allow us to calculate the proportion of OOP that is/was catastrophic for households, a global analysis of studies that included one or two SSA countries, discussion papers or general literature review that provide a general understanding of $\mathrm{CHE}$, qualitative studies that discussed CHE and methodological studies. Figure 2 represents the PRISMA flow chart for the studies selection process.

Characteristics of the included studies and quality of data Of the 34 studies assessed, half were from the West African region (11 from Nigeria), eight from the East African region (4 from Kenya), seven from the South African region ( 2 from South Africa and 2 that were comparative of South Africa with Lesotho and Mozambique respectively), one from the Central African region and one covered three SSA regions (East, West and South Africa). One could argue that literature from the Central African region was missing because the region is largely francophone, while the review focused only on English studies. However, there were several studies included from other French speaking countries including DRC, Burkina Faso, Mali, Benin, Senegal and Côte d'Ivoire. All the studies identified were observational, of which 27 were crosssectional studies, 3 were cross-sectional comparative across countries in the regions, 2 were modelled longitudinal, 1 was a case control and another a prospective observational study. 


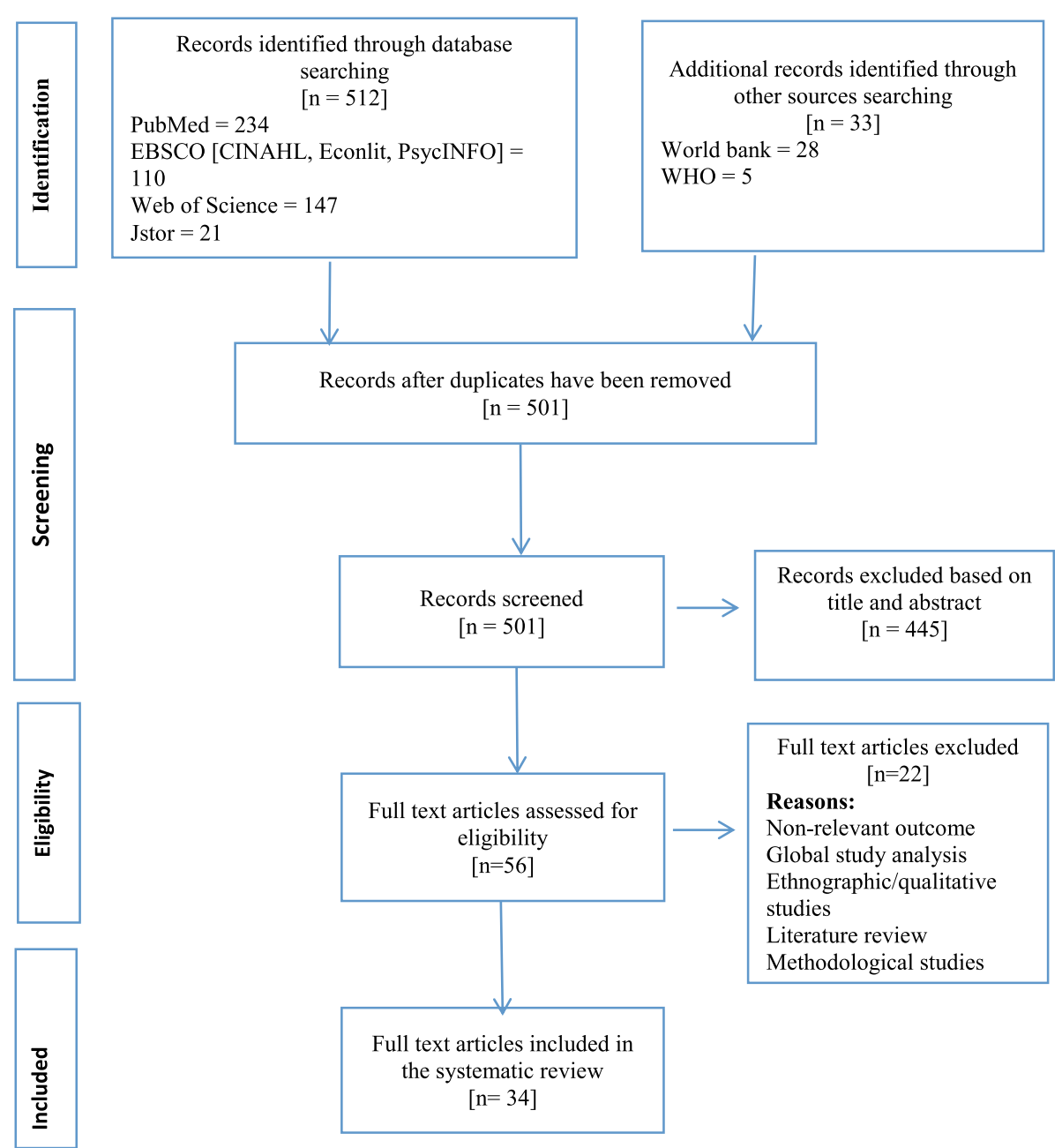

Fig. 2 PRISMA flow chart. The figure presents the flow of information through the different phases of studies selection. It maps out the number of records identified, included and excluded, and the reasons for exclusions

Nineteen (19) of the studies focused on general health care, while 15 focused on diagnostic categories including 4 on chronic (non-communicable diseases), 5 on HIV/ ART care and treatment (with one being comparison with Obstetric and TB), 2 on obstetric care (one being a comparison with TB, HIV/ART), 3 on TB (one comparison with obstetric and HIV/ART), and 3 on malaria. The number of studies increased over years with only 8 (24\%) being published between 2006 and 2011, while 26 studies (76\%) were published between 2012 and May 2017. Half of the studies covered a sub-national population within the respective country, while 14 studies (41\%) had a national coverage, and 3 studies were multi-county in that they focused on more than one country. The national studies utilised data from various national household surveys including the National Living Standard, Social Economic Survey, Poverty Monitoring Survey, Health Expenditure and Utilization Survey, while the sub national studies sampled the respective regions or specific target population. A few other studies utilised hospital data to gather data on expenses paid for the various services provided; the limitation was the small sample sizes. See Appendix 1 for all studies included in the review by various characteristics.

\section{Incidence and intensity of catastrophic health expenditure in SSA countries}

The large majority of studies focused only on the incidence of CHE $(n=23)$, while some focused on both incidence and intensity $(n=11)$, and a set of others focused on the determinants of CHE $(n=18)$. Catastrophic health expenditure varied greatly between countries. However, cross-country comparisons are difficult because of the different thresholds, sample sizes and data sets used in the various studies. Given these variations, we shall discuss the magnitude and distribution of catastrophic payments based on the most commonly used thresholds; that is $10 \%$ 
of household income [35] and 40\% of non-food expenditure [9]. Table 1 below summarizes the incidence and intensity of CHE as repoted in the articles reviewed.

The proportion of households facing catastrophic payments varied widely by the threshold applied. In most of the studies, the incidence of catastrophic expenditure was seen to be lower when higher thresholds were applied [36, 37], at $10 \%$ the average incidence of CHE was $23 \%$ while at $40 \%$ the average was $17 \%$. Generally, we noted that CHE was highest when a specific diagnostic service was assessed. Amongst the various diagnostics, HIV/ART and malaria had the highest incidence. Inpatient HIV patients in Nigeria had the highest incidence of CHE (100\%) at 10\% household expenditure, while at $40 \%$ non-food expenditure, the incidence was reduced to $94.3 \%$ [38]. There was a high incidence of CHE at $40 \%$ non-food expenditure in the Democratic republic of Congo amongst hospitalised children with severe malaria which was at $81.1 \%$ capacity to pay [39]. Both studies with a high incidence targeted specific groups of patients and thus were not national representative surveys. TB patients also incurred a high incidence of $\mathrm{CHE}$ in Benin at $71.8 \%$ at the threshold of $10 \%$ of household expenditure [40].

Variations are also observed within countries, for instance, two national studies in Nigeria that focused on CHE at $40 \%$ of non-food expenditure, one reported $\mathrm{CHE}$ of $1.7 \%$ [41], while the other [42] reported ten times more at $17.2 \%$. However, in the same studies, at $10 \%$ of household expenditure, $\mathrm{CHE}$ was closer in range at $22.7 \%$ and $25.7 \%$ respectively. Figure 3 shows the variations in the level of incidence of CHE in various Sub-Saharan countries, with many countries still experiencing high CHE over time.
The intensity of catastrophic health expenditure, which is an indication of how much expenditure exceeds the thresholds ranged from 0.1 to $25 \%$ when the $40 \%$ proportion of non-food household expenditure threshold is applied, and $1-11 \%$ when the $10 \%$ proportion of household expenditure is applied. There was relatively little difference between the intensity reported for general health care and that reported for specific diagnostics like HIV/ART, TB, malaria and chronic illnesses. Most studies on diagnostic care did not report on intensity; thus, we have less evidence to discuss the severity of $\mathrm{CHE}$ due to the use of diagnostic services and treatment. The intensity of CHE was found to be lowest amongst South African countries, while in East Africa and West Africa, the intensity was within the same range.

\section{Determinants of catastrophic health expenditure}

Eighteen (18) studies assessed the determinants of CHE in the respective countries for both general health care and specific diagnoses. The articles assessed various determinants; thus, this review will discuss the overarching determinants reported in the majority of studies. These are summarised in Table 2. See Appendix 2 for determinants reported in each of the study.

\section{Household economic/income status}

Households' income level is the most consistent determinant of catastrophic health expenditure with higherincome groups being less likely to incur CHE relative to middle income- and lower-income groups [39, 43, 44]. This is also observed amongst HIV/ART related studies. Lower-income groups had a higher likelihood of incurring CHE on ART services, given that they are more

Table 1 The incidence and intensity of CHE in SSA by regions

\begin{tabular}{|c|c|c|c|c|c|}
\hline \multirow[t]{2}{*}{ Region (countries) } & \multirow{2}{*}{$\begin{array}{l}\text { Articles that reported } \mathrm{CHE} \\
n(\%)\end{array}$} & \multicolumn{2}{|c|}{ CHE incidence: \% range [threshold] } & \multicolumn{2}{|c|}{ CHE intensity; \% range [threshold] } \\
\hline & & General health care & Diagnostics $^{1}$ & General health care & Diagnostics $^{2}$ \\
\hline $\begin{array}{l}\text { Region 1: West Africa } \\
\text { countries: Benin }=1 ; \text { Burkina Faso }=1 ; \\
\text { Côte d'lvoire }=1 ; \text { Mali }=1 ; \text { Nigeria }=11 ; \\
\text { Senegal }=1 ; \text { Ghana }=1\end{array}$ & $\begin{array}{l}17(50 \%) \\
{[2,4,5,7,10,11,15-17} \\
19-21,24,26,28,30,33]\end{array}$ & $\begin{array}{l}2.4-25.4\left[^{*}\right] \\
1.7-27\left[{ }^{* *}\right]\end{array}$ & $\begin{array}{l}8.2-71.8\left[^{*}\right] \\
9.8-44\left[^{* *}\right]\end{array}$ & $3.4-7.8\left[{ }^{*}\right]$ & $\begin{array}{l}6-7.8\left[{ }^{*}\right] \\
8.3\left[{ }^{* *}\right]\end{array}$ \\
\hline $\begin{array}{l}\text { Region 2: East Africa } \\
\text { countries: Kenya }=4 ; \text { Uganda }=2 ; \\
\text { Tanzania }=1\end{array}$ & $\begin{array}{l}8(24 \%) \\
{[1,3,6,8,9,13,31,34]}\end{array}$ & $\begin{array}{l}1.5-22.8\left[^{*}\right] \\
2.9-18\left[{ }^{* *}\right]\end{array}$ & None & $\begin{array}{l}2.5-11[*] \\
5.7-25[* *]\end{array}$ & None \\
\hline $\begin{array}{l}\text { Region 3: South African } \\
\text { countries: South Africa }=2 ; \text { Zambia }=1 ; \\
\text { Malawi }=2 ; \text { Madagascar }=1 ; \text { Botswana }=1 ; \\
\text { Lesotho }=1 ; \text { Mozambique }=1\end{array}$ & $\begin{array}{l}7(21 \%) \\
{[12,14,22,23,25,29,32]}\end{array}$ & $\begin{array}{l}0.09-11.2\left[{ }^{*}\right] \\
0.7-9.3\left[^{* *}\right]\end{array}$ & $\begin{array}{l}9-39.9\left[{ }^{*}\right] \\
4.5-34\left[{ }^{* *}\right]\end{array}$ & $\begin{array}{l}1.01[*] \\
0.1\left[{ }^{* *}\right]\end{array}$ & None \\
\hline $\begin{array}{l}\text { Region 4: Central Africa } \\
\text { countries: Democratic Republic of Congo }=1\end{array}$ & $\begin{array}{l}1(3 \%) \\
{[27]}\end{array}$ & None & $\begin{array}{l}46.4\left[^{*}\right] \\
81.1\left[{ }^{* *}\right]\end{array}$ & None & None \\
\hline $\begin{array}{l}\text { Region 5: Multi-region } \\
\text { South Africa, Ghana, Tanzania }=1\end{array}$ & $\begin{array}{l}1(3 \%) \\
{[18]}\end{array}$ & $0.1-2.4\left[{ }^{* *}\right]$ & None & None & None \\
\hline
\end{tabular}

*At $10 \%$ household income

**At 40\% non-food expenditure

${ }^{1,2}$ Malaria, HIV/ART, epilepsy, diabetes, TB, obstetric care 


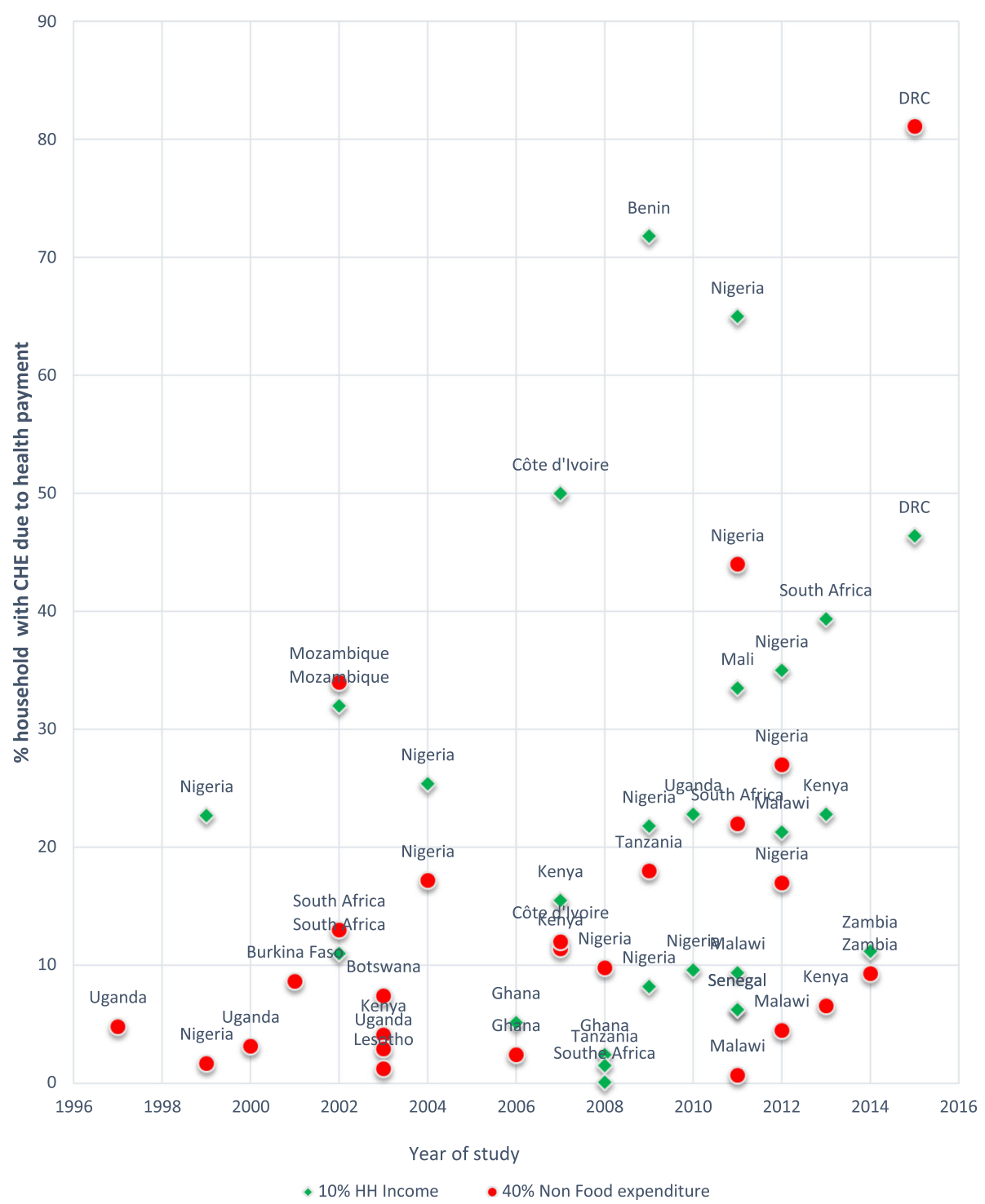

Fig. 3 The level of CHE in SSA. The figure represents the level of CHE reported in the various studies/articles across countries over time. It plots the percentage of households with CHE at thresholds of 10\% household income and $40 \%$ non-food expenditure, against the study period

likely to use their savings on food and other routine household expenditures [45]. Besides the type of disease, the power of association varied by country of study. For instance, amongst studies conducted on CHE due to tuberculosis (TB), it was found that the power of association (CHE-lower-income groups) was higher in Benin [40] than in Nigeria [46].

\section{Type of health care provider}

In case health services are provided by public hospitals, a higher CHE is observed. This is especially observed for inpatient services $[47,48]$. Within the public health care system, seeking services at the primary health care level like health centres and posts had a reducing effect on CHE $[30,49]$. In some countries, seeking care from a private health facility is associated with increased CHE relative to seeking care at public facility [50], while in others, seeking care from public and private is associated with higher CHE compared to confessional structures [39]. Seeking services from traditional healers due to cultural beliefs on various illnesses is associated with high CHE [51].

\section{Type of illness}

The presence of a household member with a chronic disease increases the likelihood of experiencing CHE $[44,51,52]$. While the number of illness episodes amongst adults significantly increases the odds of CHE; the average number of illness episodes amongst children in a household has no effect on CHE [44]. Simple illness 
Table 2 Determinants of CHE

\begin{tabular}{|c|c|c|c|c|}
\hline Determinants of catastrophic health expenditure (CHE) & Western Africa & South Africa & East and Central Africa & Total studies per determinant \\
\hline $\begin{array}{l}\text { Household economic status: } \\
\text { Poor-income households } \\
\text { Middle-income households } \\
\text { High-income households }\end{array}$ & $\begin{array}{l}4 \\
{[5,15,28,33]}\end{array}$ & $\begin{array}{l}2 \\
{[12,14]}\end{array}$ & $\begin{array}{l}4 \\
{\left[1,6,13,27^{*}\right]}\end{array}$ & 10 \\
\hline $\begin{array}{l}\text { Type of health care provider: } \\
\text { Private } \\
\text { Public }\end{array}$ & $\begin{array}{l}2 \\
{[11,24]}\end{array}$ & $\begin{array}{l}1 \\
{[14]}\end{array}$ & $\begin{array}{l}5 \\
{\left[1,9,13,27^{*}, 34\right]}\end{array}$ & 8 \\
\hline $\begin{array}{l}\text { Type of illness: } \\
\text { HIV-ART } \\
\text { Tuberculosis } \\
\text { Obstetrics } \\
\text { Malaria } \\
\text { Chronic illnesses }\end{array}$ & $\begin{array}{l}5 \\
{[5,10,11,24,33]}\end{array}$ & $\begin{array}{l}2 \\
{[12,29]}\end{array}$ & $\begin{array}{l}5 \\
{\left[1,6,9,13,27^{*}\right]}\end{array}$ & 12 \\
\hline $\begin{array}{l}\text { Household member characteristics } \\
\text { Employment status } \\
\text { Education level } \\
\text { Gender/sex } \\
\text { Age of household members }\end{array}$ & $\begin{array}{l}5 \\
{[5,15,24,28,33]}\end{array}$ & $\begin{array}{l}3 \\
{[12,22,29]}\end{array}$ & $\begin{array}{l}7 \\
{\left[1,6,9,13,27^{*}, 31,34\right]}\end{array}$ & 15 \\
\hline $\begin{array}{l}\text { Geographical location } \\
\text { Distance to the health facility } \\
\text { Residence (rural/urban) }\end{array}$ & $\begin{array}{l}3 \\
{[24,11,15]}\end{array}$ & $\begin{array}{l}3 \\
{[14,22,29]}\end{array}$ & $\begin{array}{l}5 \\
{[1,6,9,31,34]}\end{array}$ & 11 \\
\hline $\begin{array}{l}\text { Social insurance/health scheme } \\
\text { Health insurance } \\
\text { Social network scheme }\end{array}$ & $\begin{array}{l}3 \\
{[5,11,28]}\end{array}$ & Nil & $\begin{array}{l}1 \\
{[9]}\end{array}$ & 4 \\
\hline $\begin{array}{l}\text { Household size and composition } \\
\text { Number of household members } \\
\text { Household with elderly people } \\
\text { Household with under } 5 \text { children }\end{array}$ & $\begin{array}{l}5 \\
{[5,10,11,24,33]}\end{array}$ & $\begin{array}{l}2 \\
{[12,22]}\end{array}$ & $\begin{array}{l}6 \\
{[1,6,9,13,31,34]}\end{array}$ & 13 \\
\hline
\end{tabular}

*Central African region (Democratic Republic of Congo)

like coughs did not increase the risk of CHE [53]. In cases of TB care, households with an HIV patient are more likely to incur CHE than those not affected by HIV [50]. Contrary to expectation, having a disability has no effect on CHE [44]. However, occurrence of adverse events such as accidents or injury increases the likelihood of CHE [30, 53].

\section{Characteristics of household members}

Characteristics of the household head and members were mentioned in the majority of studies. However, different studies focused on different parameters including age of the household member, employment status, education level and female/male headed households. Households with older heads and older main income earners, lower education or with unemployed heads are more likely to incur CHE $[52,53]$. Full-time employment is protective against $\mathrm{CHE}$, especially amongst couples where the women has a full-time job [45]. Also, employment status and occupation are associated with CHE, for instance, having a household head who is a manual labourer increases the likelihood of CHE [16, 51, 52].

There are studies with different results, for instance, a study in Zambia shows that the education and employment status of the household head is not significantly associated with the likelihood of incurring CHE [49]. Also, a study in Nigeria finds counter intuitive evidence that more educated households are more likely to incur CHE than the less educated household [43].

There are mixed results about the probability of incurring $\mathrm{CHE}$ and gender. Female-headed households have a higher probability of facing CHE [47]. On the contrary, a study in Botswana observed that female-headed households are less likely to incur CHE [16]. In another study in Nigeria, households with a male patient are more likely to experience CHE [50], whereas in another study in Côte d'Ivoire, households of HIV-infected women have a higher risk of incurring CHE [54].

\section{Geographical location and distance to health facility}

Location of residence is seen as an important predictor of CHE. However, this varies by the location of the study. In Kenya, for instance, households located in marginalised counties have higher odds of incurring $\mathrm{CHE}$ [52], while in Benin, a study on TB patients shows the odds of CHE are higher for patients residing in urban areas, but when confounded with education, the effects disappear [40]. A study in Nigeria conducted amongst patients at a rural hospital shows that urban residents incur higher rates of catastrophic payments; this is due to transportation costs to the rural hospital [50]. Generally, living in urban areas is protective of CHE [30, 48, 
55, 56]. However, it is found to be protective for non-poor, but not for the poor [47]. Living far from the nearest health care centre is associated with increased CHE $[49,55]$.

\section{Social insurance/welfare scheme}

Informal financing mechanisms through mutual organisations, informal groups and merry go rounds unlike formal health insurance is observed to reduce the risk of CHE [43]. Thus, patients with a poor social network are more likely to incur CHE [40]. Households that are enrolled in health insurance are engaged in mutual health organisations, or an informal social safety net (such as membership in a merry go round) have a reduced risk of catastrophic spending $[30,53]$.

In certain cases, health insurance is not a significant determinant, for instance, in Kenya, because it only covers a small proportion of households and only inpatient services [48]. Health insurance is observed not to protect households from CHE due to HIV/ART services. A study in Côte d'Ivoire observed no association between $\mathrm{CHE}$ and households having health insurance. This is because households continue to cope with HIV-related costs over time, thus, the financial burden increases [54].

\section{Household size and composition}

Households size is associated with $\mathrm{CHE}$, with larger households (of more than five members) having a higher risk of incurring $\mathrm{CHE}[16,51,52,54]$.

It is observed that having an elderly member (above 65 years) in the household imposes a higher risk of $\mathrm{CHE}$ for the household, meaning that elderly people are more vulnerable [39, 47, 52]. If the household has an elderly patient, (older than 40 years) $\mathrm{CHE}$ is likely to be high $[40,50]$. In Nigeria, there seems to be a positive but not significant elderly effect [43]. Despite children being vulnerable to diseases, a study in Kenya showed that having a member aged under five decreased the odds of CHE [39].

\section{Household impoverishment in Sub Saharan-Africa countries}

Household impoverishments due to catastrophic health expenditure are measured using different poverty lines in the different studies including the subsistence poverty line, the national poverty line (NPL) and the international poverty line (IPL). A study in Uganda that used both the national $(\$ 1.31)$ and the international (\$1.25) poverty line [57] finds that the percentage poverty head count after health payment is higher when IPL is applied at $18.1 \%$, while that of the NPL was $17.1 \%$. Only one study in Malawi assesses impoverishment due to $\mathrm{CHE}$ for chronic illness [58]; all the other assessed impoverished due to $\mathrm{CHE}$ related to general health care.

The percentage of households that is impoverished ranges from 1.4 to $4.5 \%$ in the various countries. On average, $2 \%$ of households are impoverished due to health payments across all countries with Nigeria and Uganda having the largest proportion of household impoverished, $4.1 \%$ and $4.5 \%$ respectively. We note that the proportion of household impoverished in some instances increased and also decreased over time across countries and also within the countries. This is, for example, the case of Kenya in 2003, percentage of households impoverished was 1.5\%, which increased in 2007 to $2.7 \%$ and decreased in 2013 to $1.6 \%$. In Nigeria, a study using data collected in 1999 showed 2.5\% households being impoverished and 4.1\% in 2009, and in Malawi, households being impoverished were $0.9 \%$ in 2011 and $1.7 \%$ in 2012 . Out of pocket payments induced a further $5.6 \%$ (ranging from 2-7\%) of households on average into poverty with Uganda being the highest and an outlier at $18 \%$. We observe no regional variations, but within regions there are variations, for instance, in West Africa, a study in 2009 [36] found that $4.1 \%$ of households in Nigeria were impoverished due to OOP relative to $1.4 \%$ of households observed in 2011 in Senegal [30]. In East Africa, similar variations were observed, a study in Uganda showed that $4.5 \%$ of households were impoverished [57] compared to neighbouring Kenya where $2.7 \%$ [59] and $1.6 \%$ [52] households were impoverished in 2007 and 2013 respectively Fig. 4. Table 3 summarises the pre- and post-poverty head count after health care payment and the associated poverty incidence.

\section{Discussion}

We observed some limitations that should be considered when interpreting the findings. First, the studies utilised different survey data including national household surveys, targeted population surveys and hospital data. Secondly, there were variations in the measurement of expenditure with some studies including only direct medical costs while others assessed both direct and indirect medical costs [52]. Also, there were variations of the thresholds applied across the different studies to measure catastrophic health expenditure, which makes it challenging to draw direct country comparisons. Furthermore, the proportion of households that experience $\mathrm{CHE}$ is dependent on the threshold used to define it [25].

In addition, impoverishment was measured using different poverty lines including subsistence, national and international poverty line. Given the main aim was to focus on CHE studies, the articles assessed on 


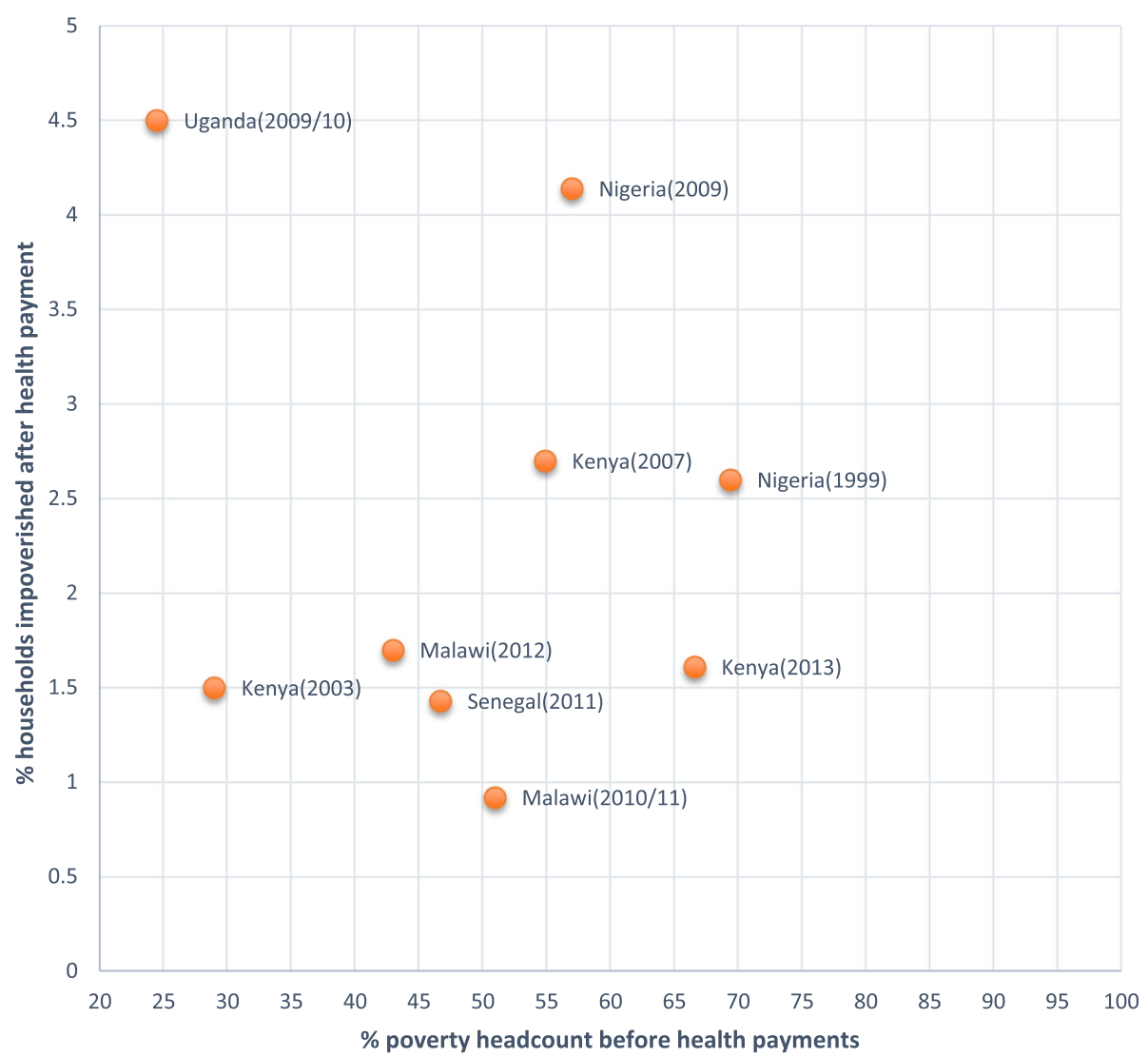

Fig. 4 Level of impoverishment. The figure represents the percentage of household impoverished after health payments against the poverty head count prior to health payments across countries

impoverishment were not exhaustive of the available literature on the same in SSA countries, but a representation of those that assessed both $\mathrm{CHE}$ and impoverishment.

We note that several studies rely on data collected several years (up to 10 years) back before the article was published, thus not providing a true reflection of the current context. Furthermore, use of alternative data means that the data was not solely collected for the purpose of this type of analysis, thus could bias the results.

The search and selection process was mainly conducted by the lead author. This could lead to a

Table $\mathbf{3}$ Impoverishment due to health payments in SSA by regions

\begin{tabular}{llllll}
\hline Author & County & $\begin{array}{l}\text { Pre-payment poverty } \\
\text { head count (\%) }\end{array}$ & $\begin{array}{l}\text { Post-payment poverty } \\
\text { head count (\%) }\end{array}$ & $\begin{array}{l}\text { Households } \\
\text { impoverished (\%) }\end{array}$ & $\begin{array}{l}\text { Relative } \\
\text { difference (\%) }\end{array}$ \\
\hline Xu et al., 2006 [47, 48] & Kenya & $29^{\boldsymbol{\alpha}}$ & 30.5 & 1.5 & 5 \\
Kwesiga et al., 2015 [57] & Uganda & $24.5^{\boldsymbol{\beta}}$ & 29 & 4.5 & 18 \\
Barasa et al., 2017 [52] & Kenya & $66.6^{\boldsymbol{\beta}}$ & 68.21 & 1.61 & 2 \\
Ichoku and Fonta, 2009 [41] & Nigeria & $69.4^{\boldsymbol{\beta}}$ & 72 & 2.6 & 4 \\
Chuma and Maina, 2012 [59] & Kenya & $54.9^{\boldsymbol{\beta}}$ & 57.6 & 2.7 & 5 \\
Sene and Cisse, 2015 [30] & Senegal & $46.71^{\boldsymbol{\beta}}$ & 48.14 & 1.43 & 3 \\
Mchenga et al., 2017 [37] & Malawi & $50.98^{\boldsymbol{\beta}}$ & 51.9 & 0.92 & 2 \\
Ichoku et al., 2009 [36] & Nigeria & $57^{\boldsymbol{\beta}}$ & 61 & 4.14 & 7 \\
Wang et al., 2016 [58] & Malawi & $43^{\varphi}$ & 44.7 & 1.7 & 4 \\
\hline
\end{tabular}

aSubsistence poverty line

${ }^{\beta}$ National poverty line

${ }^{\Phi}$ International poverty line [\$1.25 per day] 
limitation or bias in the information retrieved from the articles selected for final review. However, all authors were involved in deciding the key search words, and the search string was discussed and agreed upon by the three reviewers. At every stage of the selection process, the three authors held frequent discussions to analyse the output(s). In addition, the use of MESH terms for key journal searches like PubMed ensured that all possible words were included in the search. We note that this has no substantial impact on the findings given the final articles that were reviewed represented 17 Sub-Saharan African countries from across all the different regions and a range of health areas.

West African countries incurred higher CHE relative to the other regions. This could be because most studies utilised convenient sampling of pre-selected vulnerable groups with small sample sizes rather than national representative household economic surveys, which were largely used in other regions. Furthermore, it has been argued that the use of convenience sampling is likely to bias results and conclusions; thus, interpretation should be done with caution [28]. For instance, of the 11 studies conducted in Nigeria, only two [41, 42] utilised national representative household surveys, and we note that most studies reported different incidences of CHE.

Patients with HIV/ART, TB and malaria experience the highest incidence of catastrophic expenditure. This could largely be due to the fact that individuals with HIV continue to incur health expenses throughout the time of their illness, while those with TB are in continuous medication for about 6 months or more, and Malaria could have several repeat episodes within a family.

Studies have found that affordability of treatment in LMICs is low as large proportions of population are pushed into poverty due to medicine procurement, hence the need for subsidies [60]. However, this review revealed that non-medical related costs like transportation costs which are invariably greater for the poor living far from the health facilities, food related costs, non-routine tests and inadequate care (due to shortages of drugs and medical services) in public primary health care facilities largely influence CHE which is consistent with other studies [54, 55, $61,62]$. This therefore means that on the contrary, subsidising the cost of drugs or removal of user fees alone may not necessarily protect households from CHE. It is revealing that non-medical expenditures are much higher than medical expenditures, with food and transport being the two most significant expenditure components [38]. We note that where user fees are abolished, $\mathrm{CHE}$ declines for the non-poor but surprisingly remains the same for the poor, thus not encouraging the poor to seek care [47].

All study findings are consistent that the poor have a higher incidence and are more likely to incur CHE than the well-off. Furthermore, studies show that the poor are more burdened with out of pocket payments and catastrophic expenditure [59, 63-65]. This is largely due to the fact that for households with a low income, even a small amount of health care costs can be catastrophic [49]. This is contrary to studies in low- and middle-income countries elsewhere like Asia, whereby the well-off are seen to have a higher incidence of CHE given their likelihood to spend more on health care unlike the poor $[8,66,67]$. This demonstrates that there is significantly less financial protection going to the poorest sections of the population in Sub-Saharan African countries.

Surprisingly, seeking services from the public sector increases the risk of CHE, despite no or modest charges for public sector [68]. This is possibly because most people who seek services from public service providers are from lower-income quintiles. In most SSA countries, people who seek care in the private sector are more likely to be well-off, hence have the capacity to pay. Nevertheless, this is not the case in many other countries that show CHE to be higher amongst people seeking care in private hospitals. This could be another factor that may explain the relatively high incidence of CHE even where user fees have been removed, given the inadequate quality of services in public facilities (due to shortages of drugs and medical services), individuals are compelled to seek better care elsewhere [49].

The review underscores the role of the type of illness in CHE. Consistent with other studies that have shown the impact of non-communicable chronic illnesses [25,69], this review also notes that chronic illnesses contribute to a high risk of CHE [70-72]. Putting into consideration that infectious disease like HIV, TB and malaria are highly prevalent in Africa and have the highest incidence of CHE. This potentially poses a double burden on the households that are affected by both, thus driving the incidence of CHE further up. We observe that the time on ART decreases the risk of CHE; meaning that, patients who can access continuous ART treatment can be more financially secure [45]. However, if the main income earner is the one affected, time on ART increases the risk of CHE [54]. Contrary to the notion of collaborative HIV/TB services, we note that in case of TB care, households with HIV patients are more likely to incur CHE than those not affected by HIV because of the double disease burden [50]. 
Unlike in developed countries where health insurance is protective of CHE, this review emphasises informal social networks and mutual organisation common in the African setup, which help households to cope with costs. However, the review is inconclusive about the effect of formal health insurance in reducing CHE in SSA. There are nuances on the size of the household as a predictor of CHE. Although a larger household size is associated with higher $\mathrm{CHE}$, households with more working adults are less likely to incur CHE [53] perhaps supporting the economies of scale argument [43]. Furthermore, it is also noted that smaller households have an increased risk of CHE which reflects a smaller support network from which financial assistance can be sort [45]. Elderly members in the household are seen to increase the risk of CHE [30] unlike children less than 5 years despite both being vulnerable to illnesses. This could be due to the fact that the elderly tends to be also income earners, thus when ill, there is dual burden unlike children who are under care of an elder. This is consistent with findings in other studies [73].

Distance to the health facility is associated with an increased likelihood of CHE, highlighting the significance of distance in increasing cost of access to health care [49]. Households in rural areas are also seen to experience higher CHE relative to those in urban areas excluding slum dwellers. Similar findings are observed in studies in Vietnam, Thailand and Serbia $[6,73,74]$.

We observe that women are more likely to incur CHE due to their low financial status [43, 54]. In addition, we note that domestic violence against women increases the likelihood of experiencing CHE [51], given women's welfare is vital to the household and injustice against them affects their income contribution, health and well-being [51].

Contrary to the notion that health payments have a higher impact in countries where poverty is high [3], we observe variations in the level of impoverishments in relation to the poverty head count before health payments. For instance, in Uganda, the level of poverty before health care payment was low, but the proportion of households impoverished as a result of health payment was higher than in all other countries. The proportion of households impoverished was seen to increase over time across the various countries, with the rapidly increasing population in Africa where the majority live below the poverty line; more people could be pushed into poverty if the right financial protection measures are not put in place. It is inconclusive if impoverishment due to health care payments was permanent or transitory as no study in in this review provided for that. An answer to this could however be given using panel data which are only limited available at a national scale in SSA.

\section{Conclusions}

Overall, we observe that CHE and impoverishment are pervasive across all Sub-Saharan African countries, and the magnitude varies across and within countries and over time. The factors that keep CHE higher vary across the countries and are seen to cut across various socio-economic and demographic characteristics including economic status, type of health care provider, type of disease, household size, geographical location and social support schemes/network.

\section{Implication for research}

This review underscores the importance of studies that assess CHE in SSA, and we notice the increased interest in this area given the rise in number of studies over time. However, we observe that majority of the studies were cross sectional, thus not sufficient for overtime analysis. Further research in SSA would be more beneficial if panel data were utilised to facilitate continuous monitoring of trends and robust over-time analysis on $\mathrm{CHE}$ and impoverishment.

\section{Implications for policy}

Social protection interventions in Africa have primarily focused on the supply side through subsidising drugs, removal of user fees or provision of free health care, and most recently, expansion of social insurance schemes. However, this review has shown that most of these do not necessarily protect households from CHE due to other related non-medical costs like transport and food. The review emphasised on the role of informal social networks which are common in Africa like merry go round/mutual organisations and, hence, the need to explore policy innovations through these social networks, like insurance packages for informal/mutual groups. This review further highlights specific illnesses that drive CHE. In light of this, it is paramount for SSA countries to consider comprehensive and integrated health financing policies that cut across diseases, as this could help to draw synergies and efficiencies across disease areas and deal with possible dual disease burden. In addition, this review has paid specific attention to groups that are not financially autonomous. The fact that $\mathrm{CHE}$ was seen to be higher amongst the poor is an indication that the measures put in place have not been effective in protecting the poor. Given the context, there is a need to strengthen the social protection policies such that they are more holistic and effective in protecting the most vulnerable of population from catastrophic and impoverishing effects of health payments. 


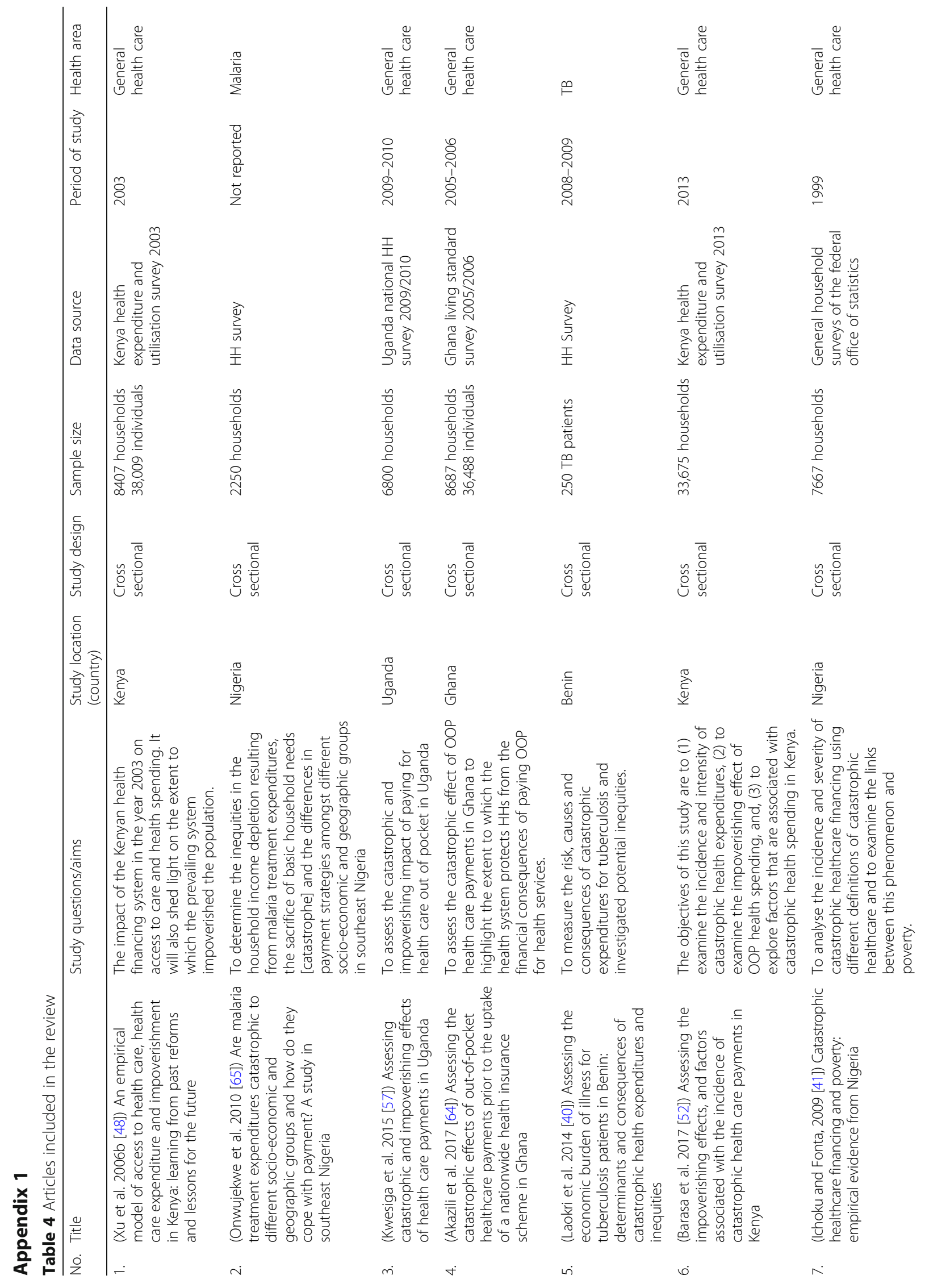




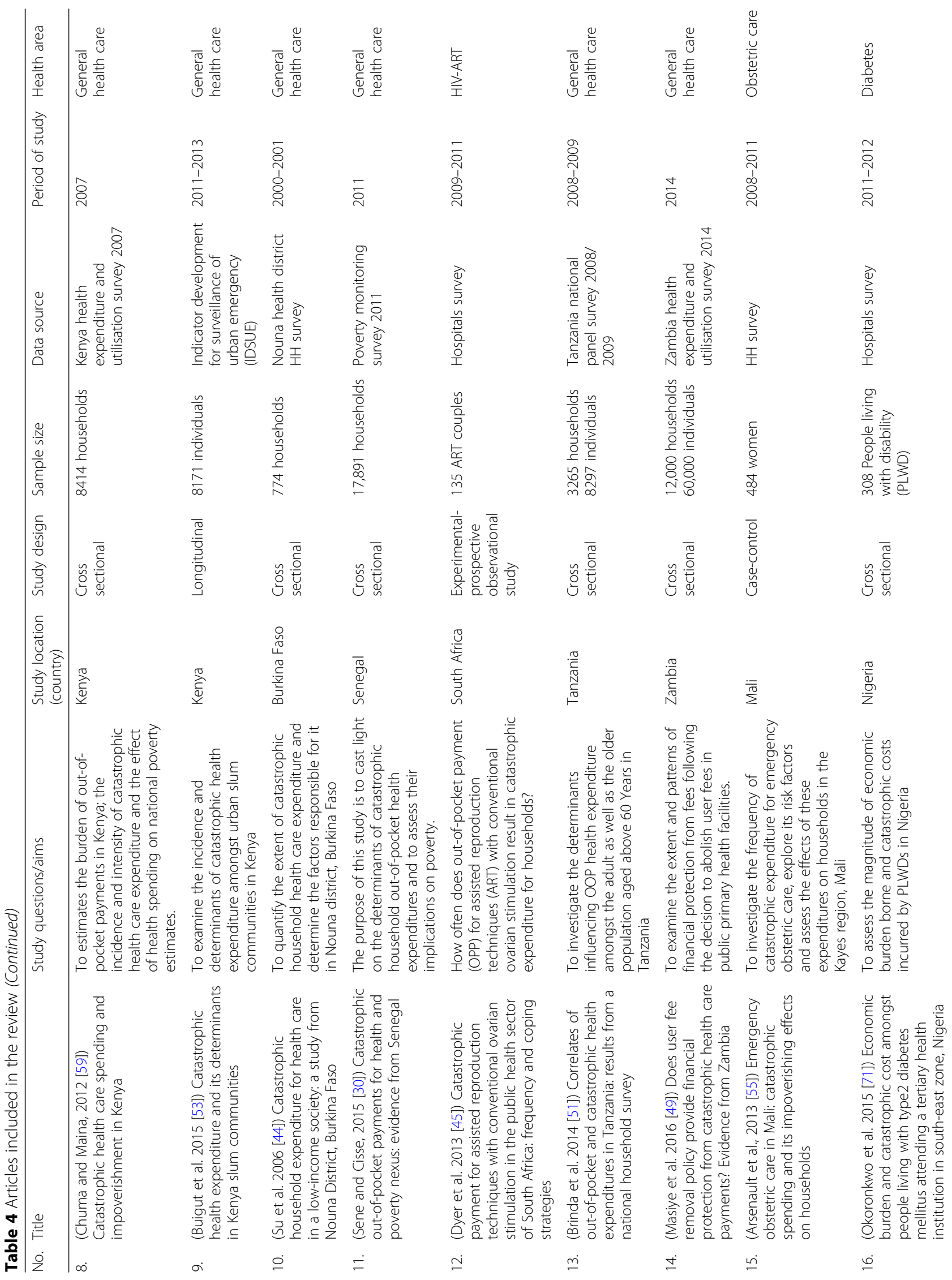




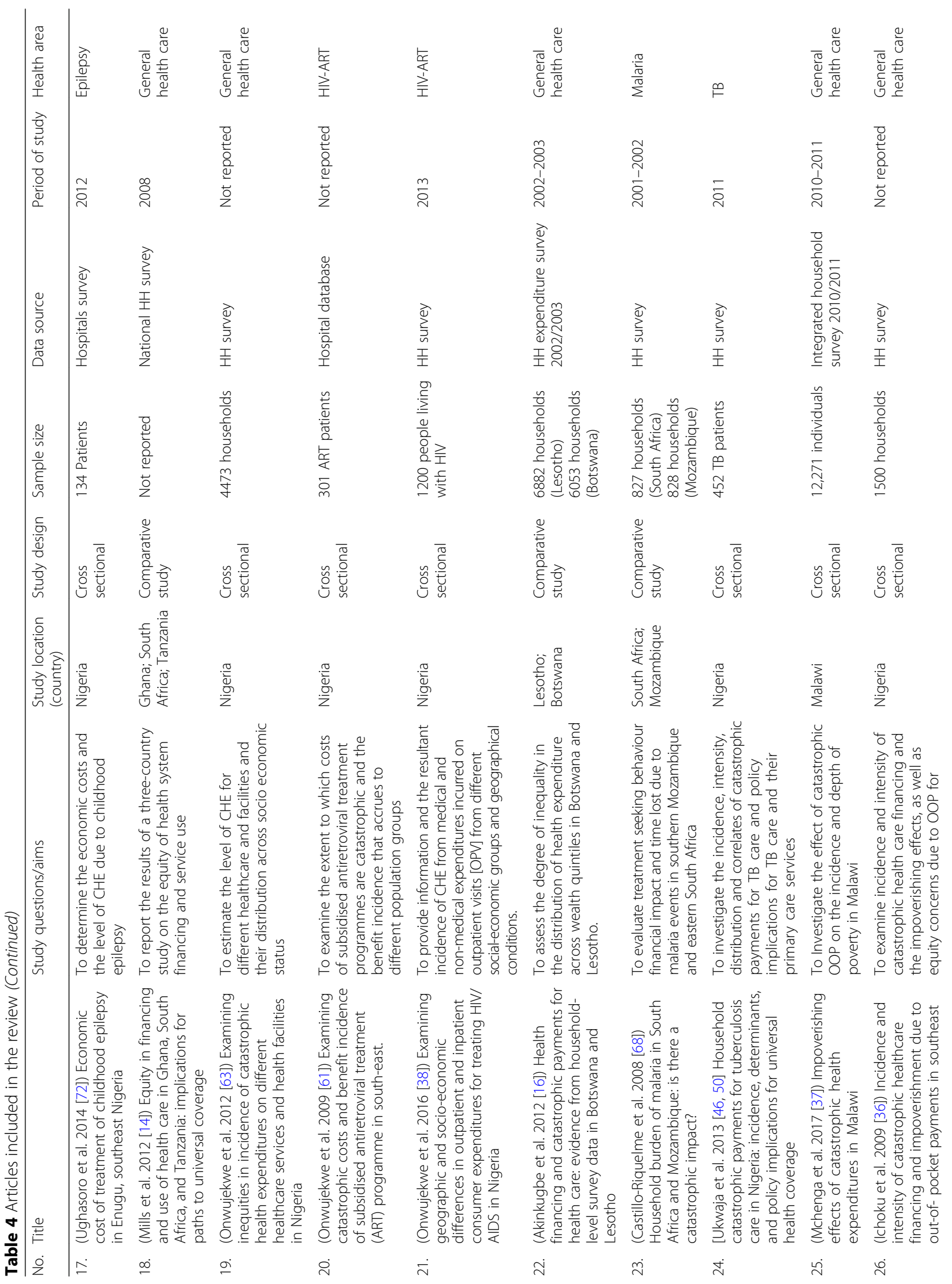




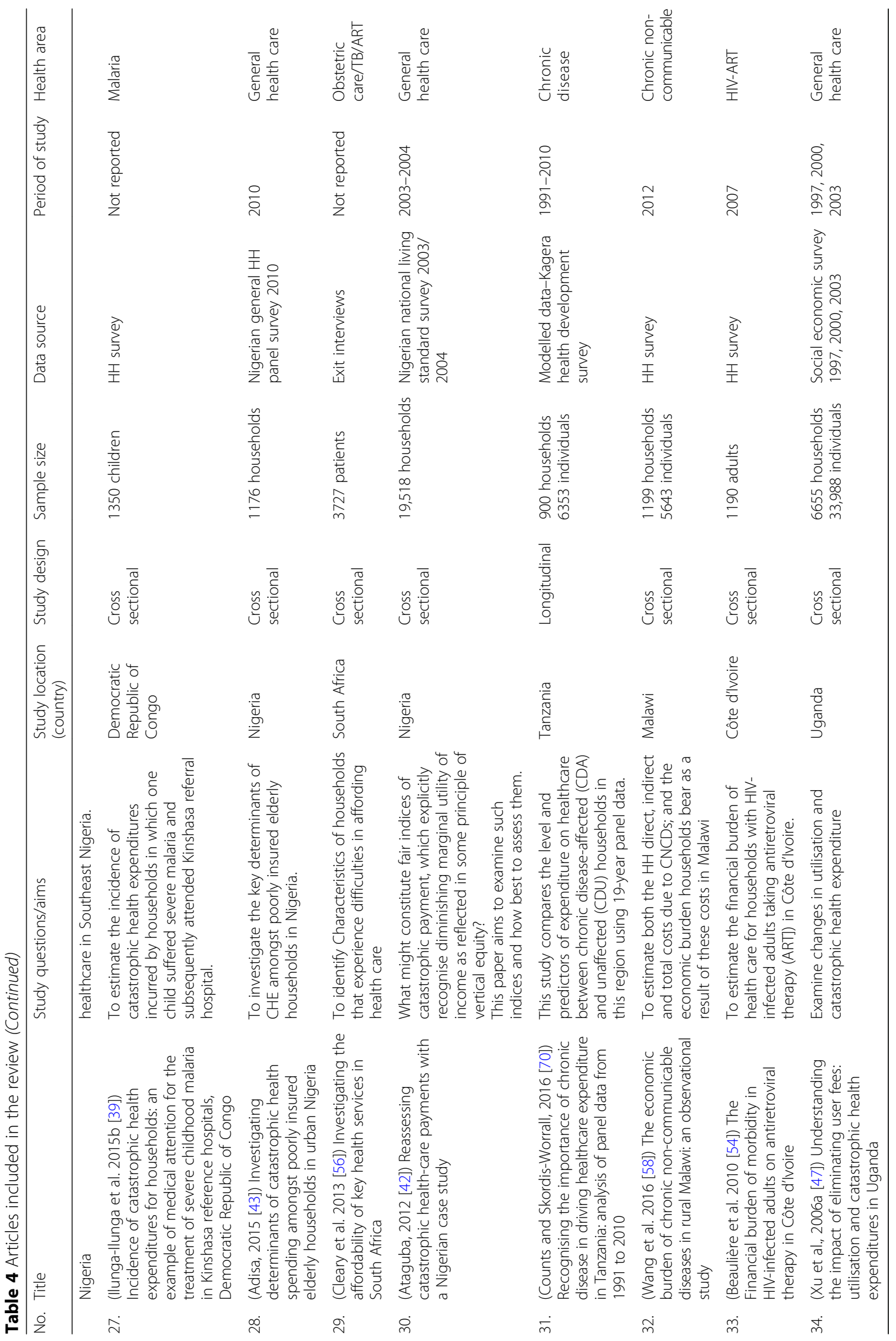




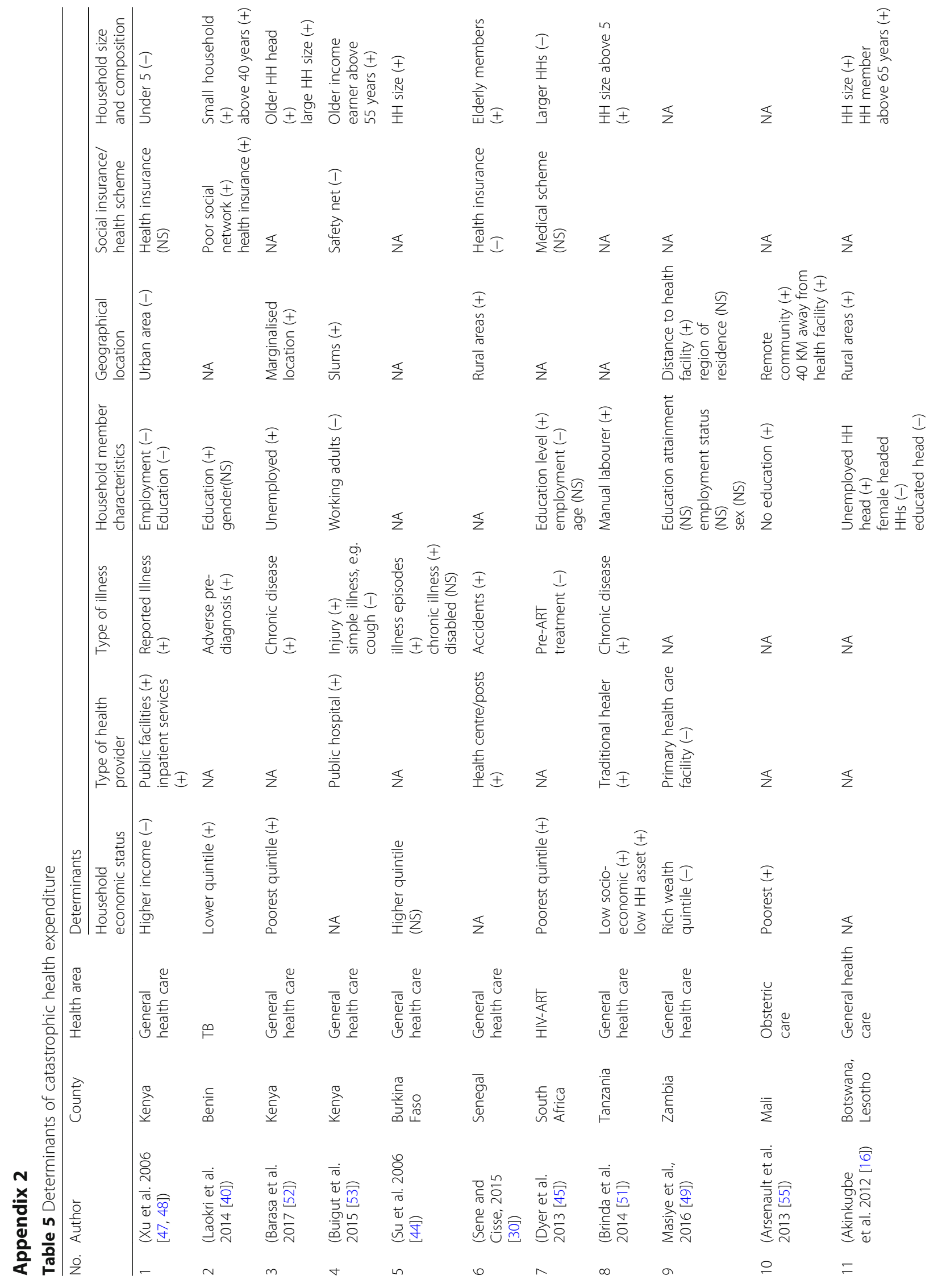


Njagi et al. Systematic Reviews (2018) 7:136

Page 18 of 23

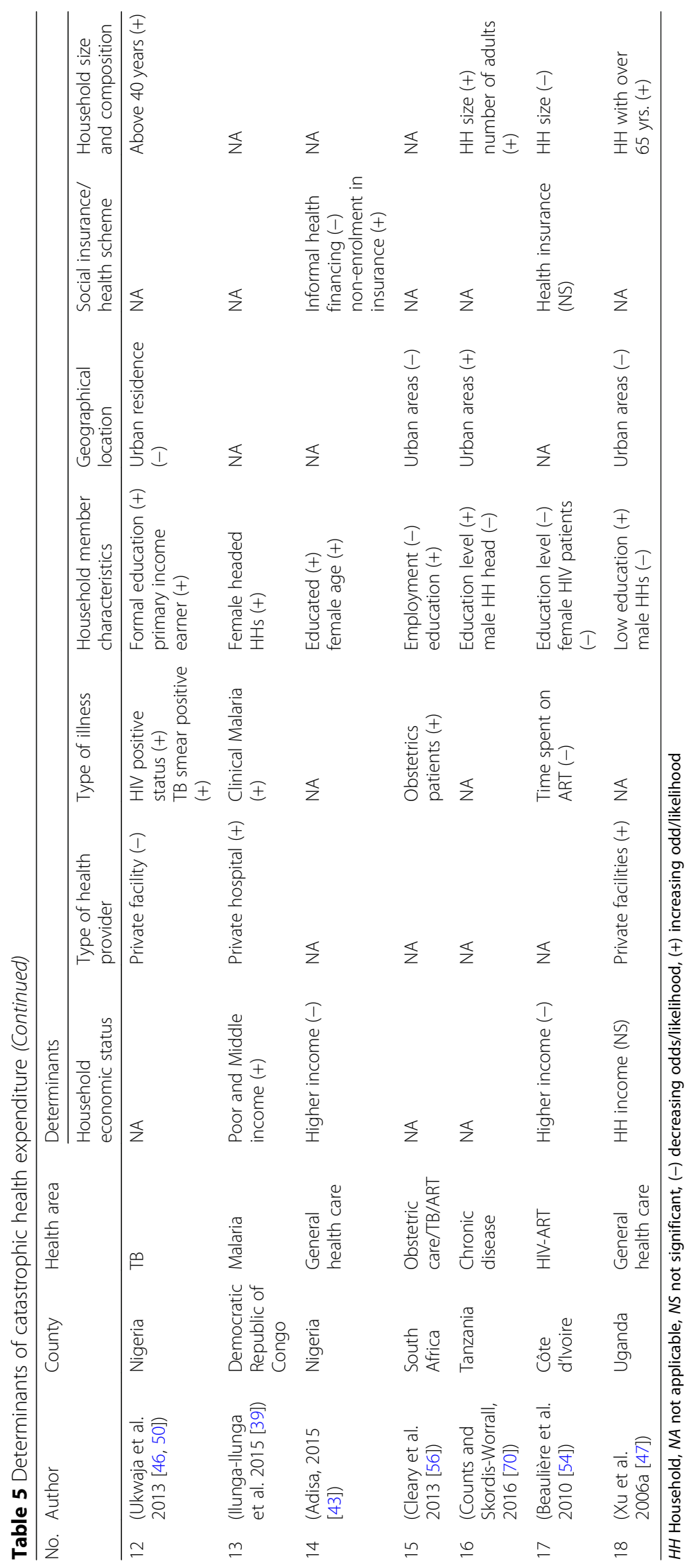




\section{Appendix 3}

Table 6 Data extracted from articles: Incidence and intensity of CHE and impoverishment reported in various articles

\begin{tabular}{|c|c|c|c|c|c|c|c|c|c|c|c|c|}
\hline No. & Author & County & $\begin{array}{l}\text { Primary } \\
\text { outcome }\end{array}$ & Threshold & Incidence range & Intensity range & $\begin{array}{l}\text { Poverty } \\
\text { Line }\end{array}$ & $\begin{array}{l}\text { Poverty } \\
\text { Head } \\
\text { count }\end{array}$ & $\begin{array}{l}\mathrm{HHs} \\
\text { Impoverished }\end{array}$ & $\begin{array}{l}\text { Out of } \\
\text { Pocket } \\
\text { expenditure }\end{array}$ & $\begin{array}{l}\text { Type of } \\
\text { costs }\end{array}$ & $\begin{array}{l}\text { Inpatient \& } \\
\text { Outpatient } \\
\text { costs }\end{array}$ \\
\hline 1 & $\begin{array}{l}\text { (Xu et al., } \\
2006)[47, \\
48]\end{array}$ & Kenya & $\begin{array}{l}\text { CHE \& } \\
\text { Impoverishment }\end{array}$ & $\begin{array}{l}40 \%-\text { Non- } \\
\text { food } \\
\text { Expenditure }\end{array}$ & $40 \%(4.1)$ & NR & $\begin{array}{l}\$ 0.5(28 \\
\text { KES) }\end{array}$ & 30.5 & $1.5 \%$ & Direct costs & $\begin{array}{l}\text { Medical } \\
\& \text { Non- } \\
\text { Medical }\end{array}$ & $\begin{array}{l}\text { Inpatient \& } \\
\text { Outpatient }\end{array}$ \\
\hline 2 & $\begin{array}{l}\text { (Onwujekwe } \\
\text { et al., 2010) } \\
{[66]}\end{array}$ & Nigeria & $\mathrm{CHE}$ & $\begin{array}{l}5 \%-\text { Non- } \\
\text { food } \\
\text { expenditure }\end{array}$ & $5 \%(8.2)$ & NR & NR & NR & NR & Direct costs & $\begin{array}{l}\text { Medical } \\
\& \text { Non- } \\
\text { Medical }\end{array}$ & Outpatient \\
\hline 3 & $\begin{array}{l}\text { (Kwesiga et } \\
\text { al., 2015) [57, } \\
\text { 59] }\end{array}$ & Uganda & $\begin{array}{l}\text { CHE \& } \\
\text { Impoverishment }\end{array}$ & $\begin{array}{l}10 \%-\mathrm{HH} \\
\text { income }\end{array}$ & $\begin{array}{l}5 \%, 10 \%, 15 \% \\
25 \%(38,22.8,15.3 \\
6.7)\end{array}$ & $\begin{array}{l}5 \%, 10 \%, 15 \% \\
25 \%(3.8,2.51 .7 \\
0.8)\end{array}$ & $\$ 1$ & $29 \%$ & $4.5 \%$ & Direct costs & Medical & Outpatient \\
\hline 4 & $\begin{array}{l}\text { (Akazili et al., } \\
\text { 2017) [65] }\end{array}$ & Ghana & CHE & $\begin{array}{l}5 \%-20 \% \\
\text { HH } \\
\text { expenditure } \\
10 \%-40 \% \\
\text { Non-food } \\
\text { expenditure }\end{array}$ & $\begin{array}{l}5 \%, 10 \%, 15 \%, 20 \% \text { - } \\
\text { HH Income, (11, } \\
5.16,3.39,2.56) \\
10 \%, 20 \%, 30 \% \\
40 \% \text { - Non-food } \\
\text { expenditure (10.7, } \\
4.91,3.17,2.43)\end{array}$ & $\begin{array}{l}5 \%, 10 \%, 15 \%, 20 \% \\
- \text { HH Income, } \\
(1.83,1.47,1.26 \\
1.11) 10 \%, 20 \% \\
40 \% \text {-Non-food } \\
\text { expenditure } \\
(3.39,2.68,2.01)\end{array}$ & NR & NR & NR & Direct costs & Medical & $\begin{array}{l}\text { Inpatient \& } \\
\text { Outpatient }\end{array}$ \\
\hline 5 & $\begin{array}{l}\text { (Laokri et al., } \\
\text { 2014) [40] }\end{array}$ & Benin & $\mathrm{CHE}$ & $\begin{array}{l}10 \%-\mathrm{HH} \\
\text { income }\end{array}$ & $\begin{array}{l}5 \%, 10 \%, 15 \% \\
20 \%, 25 \%(88.6 \\
71.8,58,45.7,36.3)\end{array}$ & $\begin{array}{l}5 \%, 10 \%, 15 \% \\
20 \%, 25 \%(12.8 \\
7.8,2.8,2.2,7.2)\end{array}$ & NR & NR & NR & Direct costs & Medical & Outpatient \\
\hline 6 & $\begin{array}{l}\text { (Barasa et al., } \\
\text { 2017) [52] }\end{array}$ & Kenya & $\begin{array}{l}\text { CHE \& } \\
\text { Impoverishment }\end{array}$ & $\begin{array}{l}40 \%-\text { Non- } \\
\text { food } \\
\text { Expenditure }\end{array}$ & $40 \%(6.58)$ & $40 \%(5.73)$ & $\begin{array}{l}\$ 0.75 \\
(29.13 \\
\text { Urban, } \\
15.62 \\
\text { Rural } \\
\text { per } \\
\text { month) }\end{array}$ & 68.21 & $1.6 \%$ & Direct costs & $\begin{array}{l}\text { Medical } \\
\& \text { Non- } \\
\text { Medical }\end{array}$ & $\begin{array}{l}\text { Inpatient \& } \\
\text { Outpatient }\end{array}$ \\
\hline 7 & $\begin{array}{l}\text { (Ichoku and } \\
\text { Fonta, 2009) } \\
{[41]}\end{array}$ & Nigeria & $\begin{array}{l}\text { CHE \& } \\
\text { Impoverishment }\end{array}$ & $\begin{array}{l}10 \%, 30 \% \\
40 \%-\mathrm{HH} \\
\text { expenditure }\end{array}$ & $\begin{array}{l}2.5 \%, 5 \%, 10 \% \\
15 \%, 20 \% \\
30 \%, 40 \%(47.8 \\
38.8,22.7,13.6,9 \\
3.5,1.7)\end{array}$ & $\begin{array}{l}2.5 \%, 10 \%, 15 \% \\
20 \%, 30 \%, 40 \% \\
(6.2,5.8,4.7,3.6 \\
2.8,1.5,0.9)\end{array}$ & $\begin{array}{l}\$ 22.2 \\
\text { per } \\
\text { month }\end{array}$ & 72 & $2.6 \%$ & NR & NR & $N R$ \\
\hline 8 & $\begin{array}{l}\text { (Chuma and } \\
\text { Maina, 2012) } \\
{[60]}\end{array}$ & Kenya & $\begin{array}{l}\text { CHE \& } \\
\text { Impoverishment }\end{array}$ & $\begin{array}{l}10 \%-\mathrm{HH} \\
\text { expenditure } \\
\& 40 \%- \\
\text { Non-food } \\
\text { expenditure }\end{array}$ & $\begin{array}{l}10 \%, 25 \%, 40 \% \\
(15.5,16,11.4)\end{array}$ & $\begin{array}{l}10 \%, 25 \%, 40 \% \\
(11,27.2,25.4)\end{array}$ & $\begin{array}{l}\$ 0.5 \\
(1257 \\
\text { KES per } \\
\text { month) }\end{array}$ & 57.6 & $2.7 \%$ & Direct costs & Medical & $\begin{array}{l}\text { Inpatient \& } \\
\text { Outpatient }\end{array}$ \\
\hline 9 & $\begin{array}{l}\text { (Buigut et al., } \\
\text { 2015) [53] }\end{array}$ & Kenya & $\mathrm{CHE}$ & $\begin{array}{l}10 \% \mathrm{HH} \\
\text { income }\end{array}$ & $\begin{array}{l}10 \%, 15 \%, 20 \% \\
30 \%(22.8,4.11 \\
2.7,1.55)\end{array}$ & NR & NR & NR & NR & Direct costs & $\begin{array}{l}\text { Medical } \\
\& \text { Non- } \\
\text { Medical }\end{array}$ & Outpatient \\
\hline 10 & $\begin{array}{l}\text { (Su et al., } \\
\text { 2006) [44] }\end{array}$ & $\begin{array}{l}\text { Burkina } \\
\text { Faso }\end{array}$ & $\mathrm{CHE}$ & $\begin{array}{l}40 \%-\text { Non- } \\
\text { food } \\
\text { Expenditure }\end{array}$ & $\begin{array}{l}20 \%, 30 \%, 40 \% \\
(15.12,10.59,8.66)\end{array}$ & NR & NR & NR & NR & Direct costs & $\begin{array}{l}\text { Medical } \\
\& \text { Non- } \\
\text { Medical }\end{array}$ & $\begin{array}{l}\text { Inpatient \& } \\
\text { Outpatient }\end{array}$ \\
\hline 11 & $\begin{array}{l}\text { (Sene and } \\
\text { Cisse, 2015) } \\
{[30]}\end{array}$ & Senegal & $\begin{array}{l}\text { CHE \& } \\
\text { Impoverishment }\end{array}$ & $\begin{array}{l}10 \%-\mathrm{HH} \\
\text { expenditure }\end{array}$ & $\begin{array}{l}5 \%, 10 \%, 15 \%, 20 \% \\
25 \%(16.2,6.26 \\
2.33,1.38,0.87)\end{array}$ & NR & $\$ 1$ & 48.14 & $1.4 \%$ & Direct costs & $\begin{array}{l}\text { Medical } \\
\& \text { Non- } \\
\text { Medical }\end{array}$ & $\begin{array}{l}\text { Inpatient \& } \\
\text { Outpatient }\end{array}$ \\
\hline 12 & $\begin{array}{l}\text { (Dyer et al., } \\
\text { 2013) [45] }\end{array}$ & South Africa & $\mathrm{CHE}$ & $\begin{array}{l}40 \%-\text { Non- } \\
\text { food } \\
\text { Expenditure }\end{array}$ & $40 \%(22)$ & NR & NR & NR & NR & $\begin{array}{l}\text { Direct \& } \\
\text { Indirect } \\
\text { costs }\end{array}$ & $\begin{array}{l}\text { Medical } \\
\text { \& Non- } \\
\text { Medical }\end{array}$ & Outpatient \\
\hline 13 & $\begin{array}{l}\text { (Brinda et al., } \\
\text { 2014) [51] }\end{array}$ & Tanzania & $\mathrm{CHE}$ & $\begin{array}{l}40 \%-\text { Non- } \\
\text { food } \\
\text { Expenditure }\end{array}$ & $40 \%(18)$ & NR & NR & NR & NR & Direct costs & Medical & $\begin{array}{l}\text { Inpatient \& } \\
\text { Outpatient }\end{array}$ \\
\hline 14 & $\begin{array}{l}\text { Masiye et al., } \\
\text { 2016) [49] }\end{array}$ & Zambia & $\mathrm{CHE}$ & $\begin{array}{l}10 \%-\mathrm{HH} \\
\text { income \& } \\
40 \% \text { - Non- } \\
\text { food } \\
\text { expenditure }\end{array}$ & $\begin{array}{l}10 \%, 40 \%(11.2 \\
9.3)\end{array}$ & NR & NR & NR & NR & Direct costs & $\begin{array}{l}\text { Medical } \\
\& \text { Non- } \\
\text { Medical }\end{array}$ & Outpatient \\
\hline 15 & $\begin{array}{l}\text { (Arsenault et } \\
\text { al., 2013) [55] }\end{array}$ & Mali & $\mathrm{CHE}$ & $\begin{array}{l}10 \%-\mathrm{HH} \\
\text { income }\end{array}$ & $\begin{array}{l}5 \%, 10 \%, 15 \% \\
(53.5,33.5,20.7)\end{array}$ & $N R$ & NR & NR & NR & Direct costs & $\begin{array}{l}\text { Medical } \\
\text { \& Non- } \\
\text { Medical }\end{array}$ & Outpatient \\
\hline 16 & $\begin{array}{l}\text { (Okoronkwo } \\
\text { et al., 2015) } \\
{[72]}\end{array}$ & Nigeria & $\mathrm{CHE}$ & $\begin{array}{l}30 \%-\text { Non- } \\
\text { food } \\
\text { Expenditure }\end{array}$ & $30 \%(45)$ & NR & NR & NR & NR & Direct costs & $\begin{array}{l}\text { Medical } \\
\& \text { Non- } \\
\text { Medical }\end{array}$ & Outpatient \\
\hline 17 & $\begin{array}{l}\text { Ughasoro et } \\
\text { al., 2014) [73] }\end{array}$ & Nigeria & $\mathrm{CHE}$ & $\begin{array}{l}40 \%-\text { Non- } \\
\text { food } \\
\text { Expenditure }\end{array}$ & $\begin{array}{l}\text { 40\% (Inpatient- } \\
\text { 63.6, Outpatient } \\
\text { 34.1) }\end{array}$ & NR & NR & NR & NR & Direct costs & $\begin{array}{l}\text { Medical } \\
\& \text { Non- } \\
\text { Medical }\end{array}$ & $\begin{array}{l}\text { Inpatient \& } \\
\text { Outpatient }\end{array}$ \\
\hline 18 & $\begin{array}{l}\text { (Mills et al., } \\
\text { 2012) [14] }\end{array}$ & $\begin{array}{l}\text { Ghana; } \\
\text { South } \\
\text { Africa; }\end{array}$ & $\mathrm{CHE}$ & $\begin{array}{l}40 \%-\text { Non- } \\
\text { food } \\
\text { Expenditure }\end{array}$ & $\begin{array}{l}\text { 40\% (Ghana-2.43, } \\
\text { Tanzania-1.52, } \\
\text { South Africa-0.09) }\end{array}$ & NR & NR & NR & NR & Direct costs & NR & $N R$ \\
\hline
\end{tabular}


Table 6 Data extracted from articles: Incidence and intensity of CHE and impoverishment reported in various articles (Continued)

\begin{tabular}{|c|c|c|c|c|c|c|c|c|c|c|c|c|}
\hline No. & Author & County & $\begin{array}{l}\text { Primary } \\
\text { outcome }\end{array}$ & Threshold & Incidence range & Intensity range & $\begin{array}{l}\text { Poverty } \\
\text { Line }\end{array}$ & $\begin{array}{l}\text { Poverty } \\
\text { Head } \\
\text { count }\end{array}$ & $\begin{array}{l}\text { HHs } \\
\text { Impoverished }\end{array}$ & $\begin{array}{l}\text { Out of } \\
\text { Pocket } \\
\text { expenditure }\end{array}$ & $\begin{array}{l}\text { Type of } \\
\text { costs }\end{array}$ & $\begin{array}{l}\text { Inpatient \& } \\
\text { Outpatient } \\
\text { costs }\end{array}$ \\
\hline$\overline{19}$ & $\begin{array}{l}\text { (Onwujekwe } \\
\text { et al., 2012) } \\
\text { [64] }\end{array}$ & Nigeria & $\mathrm{CHE}$ & $\begin{array}{l}40 \%-\text { Non- } \\
\text { food } \\
\text { Expenditure }\end{array}$ & $5 \%, 40 \%(57,27)$ & NR & NR & $\mathrm{NR}$ & NR & Direct costs & $\begin{array}{l}\text { Not } \\
\text { indicated }\end{array}$ & $\begin{array}{l}\text { Inpatient \& } \\
\text { Outpatient }\end{array}$ \\
\hline 20 & $\begin{array}{l}\text { (Onwujekwe } \\
\text { et al., 2009) } \\
\text { [62] }\end{array}$ & Nigeria & $\mathrm{CHE}$ & $\begin{array}{l}40 \%-\text { Non- } \\
\text { food } \\
\text { Expenditure }\end{array}$ & $40 \%(9.8)$ & NR & NR & NR & NR & Direct costs & $\begin{array}{l}\text { Medical } \\
\text { \& Non- } \\
\text { Medical }\end{array}$ & Outpatient \\
\hline 21 & $\begin{array}{l}\text { (Onwujekwe } \\
\text { et al., 2016) } \\
\text { [38] }\end{array}$ & Nigeria & $\mathrm{CHE}$ & $\begin{array}{l}40 \% \text { - Non- } \\
\text { food } \\
\text { Expenditure }\end{array}$ & $\begin{array}{l}\text { 10\%, 40\% } \\
\text { (Inpatient-100, } \\
\text { 40.3: Outpatient- } \\
94.3,7.7)\end{array}$ & NR & NR & NR & NR & Direct costs & $\begin{array}{l}\text { Medical } \\
\& \text { Non- } \\
\text { Medical }\end{array}$ & $\begin{array}{l}\text { Inpatient \& } \\
\text { Outpatient }\end{array}$ \\
\hline 22 & $\begin{array}{l}\text { (Akinkugbe } \\
\text { et al., 2012) } \\
{[16]}\end{array}$ & $\begin{array}{l}\text { Botswana, } \\
\text { Lesotho }\end{array}$ & $\begin{array}{l}\text { CHE \& } \\
\text { Impoverishment }\end{array}$ & $\begin{array}{l}20 \% \text { Non- } \\
\text { food } \\
\text { Expenditure } \\
\& 40 \%- \\
\text { Non-food } \\
\text { Expenditure }\end{array}$ & $\begin{array}{l}\text { 20\%, 40\% } \\
\text { (Botswana-11.1, } \\
\text { 3.22: Lesotho-7.43, } \\
1.25 \text { ) }\end{array}$ & NR & NR & NR & NR & Direct costs & $\begin{array}{l}\text { Medical } \\
\text { \& Non- } \\
\text { Medical }\end{array}$ & $\begin{array}{l}\text { Not } \\
\text { indicated }\end{array}$ \\
\hline 23 & $\begin{array}{l}\text { (Castillo- } \\
\text { Riquelme et } \\
\text { al., 2008) [69] }\end{array}$ & South Africa & $\mathrm{CHE}$ & $\begin{array}{l}10 \%-\mathrm{HH} \\
\text { income \& } \\
40 \% \text { - Non- } \\
\text { food } \\
\text { expenditure }\end{array}$ & $\begin{array}{l}10 \%, 40 \% \\
\text { (Mozambique-32, } \\
\text { 34; Kwazulu Natal- } \\
\text { 11.4, 12.5; } \\
\text { Mpumalanga-10.2, } \\
\text { 9) }\end{array}$ & NR & NR & NR & NR & $\begin{array}{l}\text { Direct \& } \\
\text { Indirect } \\
\text { costs }\end{array}$ & Medical & $\begin{array}{l}\text { Inpatient \& } \\
\text { Outpatient }\end{array}$ \\
\hline 24 & $\begin{array}{l}\text { (Ukwaja et } \\
\text { al., 2013) [46, } \\
50]\end{array}$ & Nigeria & $\mathrm{CHE}$ & $\begin{array}{l}10 \%-\mathrm{HH} \\
\text { income \& } \\
40 \% \text { - Non- } \\
\text { food } \\
\text { expenditure }\end{array}$ & $\begin{array}{l}10 \%, 15 \%, 25 \% \\
40 \%(65,84,68, \\
44)\end{array}$ & $\begin{array}{l}10 \%, 15 \%, 25 \% \\
40 \%(6,12.3,10.7 \\
8.3)\end{array}$ & NR & NR & NR & Direct costs & $\begin{array}{l}\text { Medical } \\
\text { \& Non- } \\
\text { Medical }\end{array}$ & Outpatient \\
\hline 25 & $\begin{array}{l}\text { (Mchenga et } \\
\text { al., 2017) [37] }\end{array}$ & Malawi & $\begin{array}{l}\text { CHE \& } \\
\text { Impoverishment }\end{array}$ & $\begin{array}{l}10 \% \text { - Non- } \\
\text { food } \\
\text { expenditure } \\
\& 40 \% \text { - } \\
\text { Non-food } \\
\text { expenditure }\end{array}$ & $\begin{array}{l}10 \%, 20 \%, 30 \% \\
40 \%(9.37,3.41 \\
1.6,0.7)\end{array}$ & $\begin{array}{l}10 \%, 20 \%, 30 \%, \\
40 \%(1.01,0.43, \\
0.2,0.08)\end{array}$ & $\begin{array}{l}\$ 0.6 \\
\text { (K37002 } \\
\text { Per } \\
\text { annum) }\end{array}$ & 51.9 & $0.9 \%$ & Direct costs & $\begin{array}{l}\text { Not } \\
\text { Indicated }\end{array}$ & $\begin{array}{l}\text { Not } \\
\text { indicated }\end{array}$ \\
\hline 26 & $\begin{array}{l}\text { (Ichoku et al., } \\
\text { 2009) [36] }\end{array}$ & Nigeria & $\begin{array}{l}\text { CHE \& } \\
\text { Impoverishment }\end{array}$ & $\begin{array}{l}5 \%-\mathrm{HH} \\
\text { expenditure } \\
\& 10 \% \mathrm{HH} \\
\text { expenditure }\end{array}$ & $\begin{array}{l}5 \%, 10 \%(29, \\
21.75)\end{array}$ & $\begin{array}{l}5 \%, 10 \%(5.67, \\
4.4)\end{array}$ & $\begin{array}{l}\$ 1 \\
\text { (N2900 } \\
\text { per } \\
\text { month) }\end{array}$ & 61 & $4.1 \%$ & Direct costs & $\begin{array}{l}\text { Medical } \\
\& \text { Non- } \\
\text { Medical }\end{array}$ & Outpatient \\
\hline 27 & $\begin{array}{l}\text { (llunga- } \\
\text { Ilunga et al., } \\
\text { 2015) [39] }\end{array}$ & $\begin{array}{l}\text { Democratic } \\
\text { Republic of } \\
\text { Congo }\end{array}$ & $\mathrm{CHE}$ & $\begin{array}{l}10 \%-\mathrm{HH} \\
\text { expenditure } \\
\& 40 \%- \\
\text { Non-food } \\
\text { expenditure }\end{array}$ & $\begin{array}{l}10 \%, 40 \%(65.3, \\
94.7)\end{array}$ & NR & NR & NR & NR & Direct costs & $\begin{array}{l}\text { Not } \\
\text { Indicated }\end{array}$ & Inpatient \\
\hline 28 & $\begin{array}{l}\text { (Adisa, 2015) } \\
\text { [43] }\end{array}$ & Nigeria & $\mathrm{CHE}$ & $\begin{array}{l}10 \%-\mathrm{HH} \\
\text { expenditure }\end{array}$ & $10 \%(9.61)$ & NR & NR & NR & NR & Direct costs & Medical & $\begin{array}{l}\text { Inpatient \& } \\
\text { Outpatient }\end{array}$ \\
\hline 29 & $\begin{array}{l}\text { (Cleary et al., } \\
\text { 2013) [56] }\end{array}$ & South Africa & $\mathrm{CHE}$ & $\begin{array}{l}10 \%-\mathrm{HH} \\
\text { expenditure }\end{array}$ & $\begin{array}{l}\text { 10\% (All 39.35 } \\
\text { TB-32.9, ART- 22.7, } \\
\text { CEOC-66.1) }\end{array}$ & NR & NR & NR & NR & Direct costs & $\begin{array}{l}\text { Medical } \\
\text { \& Non- } \\
\text { Medical }\end{array}$ & $\begin{array}{l}\text { Inpatient \& } \\
\text { Outpatient }\end{array}$ \\
\hline 30 & $\begin{array}{l}\text { (Ataguba, } \\
\text { 2012) [42] }\end{array}$ & Nigeria & $\mathrm{CHE}$ & $\begin{array}{l}10 \%-\mathrm{HH} \\
\text { expenditure } \\
\& 40 \% \text { - } \\
\text { Non-food } \\
\text { expenditure }\end{array}$ & $\begin{array}{l}10 \%, 15 \%, 20 \% \\
40 \%(25.4,19.6 \\
15.6,17.2)\end{array}$ & $\begin{array}{l}10 \%, 15 \%, 20 \%, \\
40 \%(6.01,4.9 \\
4.02,4.9)\end{array}$ & NR & NR & NR & Direct costs & Medical & $\begin{array}{l}\text { Not } \\
\text { Indicated }\end{array}$ \\
\hline 31 & $\begin{array}{l}\text { (Counts and } \\
\text { Skordis- } \\
\text { Worrall, } \\
\text { 2016) [71] }\end{array}$ & Tanzania & $\mathrm{CHE}$ & $\begin{array}{l}40 \%-\text { Non- } \\
\text { food } \\
\text { Expenditure }\end{array}$ & $\begin{array}{l}40 \% \text { (Affected-7.5, } \\
\text { Un affected - } 6.7 \text { ) }\end{array}$ & NR & NR & NR & NR & Direct costs & $\begin{array}{l}\text { Medical } \\
\text { \& Non- } \\
\text { Medical }\end{array}$ & $\begin{array}{l}\text { Inpatient \& } \\
\text { Outpatient }\end{array}$ \\
\hline 32 & $\begin{array}{l}\text { (Wang et al., } \\
\text { 2016) [58] }\end{array}$ & Malawi & $\begin{array}{l}\text { CHE \& } \\
\text { Impoverishment }\end{array}$ & $\begin{array}{l}10 \% \text { - Non- } \\
\text { food } \\
\text { expenditure } \\
\& 40 \% \text { - } \\
\text { Non-food } \\
\text { expenditure }\end{array}$ & $\begin{array}{l}10 \%, 25 \%, 40 \% \\
(21.3,10.7,4.5)\end{array}$ & NR & $\$ 1.25$ & 44.7 & $1.7 \%$ & $\begin{array}{l}\text { Direct costs } \\
\& \text { Indirect } \\
\text { costs }\end{array}$ & $\begin{array}{l}\text { Medical } \\
\text { \& Non- } \\
\text { Medical }\end{array}$ & Outpatient \\
\hline 33 & $\begin{array}{l}\text { (Beaulière et } \\
\text { al., 2010) [54, } \\
74]\end{array}$ & $\begin{array}{l}\text { Côte } \\
\text { d'Ivoire }\end{array}$ & $\mathrm{CHE}$ & $\begin{array}{l}40 \%-\text { Non- } \\
\text { food } \\
\text { Expenditure }\end{array}$ & $\begin{array}{l}10 \%, 20 \%, 40 \% \\
(50,28,12)\end{array}$ & NR & NR & NR & NR & Direct costs & $\begin{array}{l}\text { Medical } \\
\& \text { Non- } \\
\text { Medical }\end{array}$ & Outpatient \\
\hline 34 & $\begin{array}{l}\text { (Xu et al., } \\
\text { 2006a) [47] }\end{array}$ & Uganda & $\mathrm{CHE}$ & $\begin{array}{l}40 \%-\text { Non- } \\
\text { food } \\
\text { Expenditure }\end{array}$ & $\begin{array}{l}40 \%(1997-4.82 \\
2000-3.15,2003-2.92)\end{array}$ & NR & NR & NR & NR & Direct costs & Medical & $\begin{array}{l}\text { Not } \\
\text { indicated }\end{array}$ \\
\hline
\end{tabular}




\section{Additional files}

Additional file 1: PRISMA Checklist. This is PRISMA (Preferred Reporting Items for Systematic review and Meta-Analysis) checklist with the recommended items addressed in the review. (DOCX $26 \mathrm{~kb}$ )

Additional file 2: Search string. This is a summary of the search chain applied to search for articles in the various databases. (DOCX $77 \mathrm{~kb}$ )

Additional file 3: Quality assessment tool. This is the Quality Assessment Tool for Observational Cohort and Cross-Sectional Studies used to assess the quality of the articles included in this review. (DOCX $96 \mathrm{~kb}$ )

\section{Abbreviations}

ART: Antiretroviral therapy; AU: African Union; CHE: Catastrophic health expenditure; HIV: Human immunodeficiency virus; LMIC: Low- and middleincome countries; OOP: Out of pocket; PRISMA: Preferred Reporting Items for Systematic Reviews and Meta-Analyses; SSA: Sub-Saharan Africa; TB: Tuberculosis; UHC: Universal Health Coverage; WHO: World Health Organization

\section{Availability of data and materials}

Detailed search strings are attached in Additional file s2, and all the articles assessed are provided in Appendix 1.

\section{Authors' contributions}

PN designed the scope of the review, the search strategy, conducted the search, screened citations, read and appraised the literature, summarised findings, constructed the figures and tables and prepared the draft manuscript. WG and JA provided inputs into the scope of the review, the search strategy, quality of articles review, structure of the manuscript and reviewed all the draft versions. All the authors read and approved the final manuscript.

\section{Authors' information}

PN is a PhD Fellow/Researcher at the United Nations University-MERIT, School of Governance, Maastricht University, the Netherlands.

\section{Ethics approval and consent to participate}

Not applicable.

\section{Consent for publication}

Not applicable.

\section{Competing interests}

The authors declare that they have no competing interests.

\section{Publisher's Note}

Springer Nature remains neutral with regard to jurisdictional claims in published maps and institutional affiliations.

\section{Author details}

${ }^{1}$ United Nations University - Maastricht Economic and social Research institute on Innovation and Technology(UNU-MERIT), Maastricht University, Maastricht, The Netherlands. 'Department of Health Services Research, Faculty of Health Medicine and Life Sciences, Maastricht University, Maastricht, The Netherlands. ${ }^{3}$ Faculty of Law, Economics and Governance, Utrecht University, Utrecht, The Netherlands.

Received: 8 January 2018 Accepted: 20 August 2018 Published online: 11 September 2018

\section{References}

1. Fortney JC, Burgess JF, Bosworth HB, Booth BM, Kaboli PJ. A re-conceptualization of access for 21st century healthcare. J Gen Intern Med. 2011;26:639-47.

2. Bright T, Felix L, Kuper H, Polack S. A systematic review of strategies to increase access to health services among children in low and middle income countries. BMC Health Serv Res. 2017;17 https://doi.org/10.1186/ s12913-017-2180-9

3. J L Murray C, Xu K, Klavus J, Kawabata K, Hanvoravongchai P, Zeramdini R, et al. Assessing the distribution of household financial contributions to the health system: concepts and empirical application. Health systems performance assessment : debates, methods and empiricism. 2003;513-31.
4. Xu K, Organization WH, et al. Distribution of health payments and catastrophic expenditures methodology. 2005. http://www.who.int/iris/ handle/10665/69030. Accessed 28 Sep 2017

5. Ezat Wan Puteh S, Almualm Y. Catastrophic health expenditure among developing countries. Health Syst Policy Res. 2017;04 https://doi.org/10. 21767/2254-9137.100069.

6. Limwattananon S, Tangcharoensathien V, Prakongsai P. Catastrophic and poverty impacts of health payments: results from national household surveys in Thailand. Bull World Health Organ. 2007;85:600-6.

7. Xu K, Evans DB, Kawabata K, Zeramdini R, Klavus J, Murray CJL. Understanding Household Catastrophic Health Expenditures: a Multicountry Analysis. 2003;565-72.

8. van Doorslaer E, O'Donnell O, Rannan-Eliya RP, Somanathan A, Adhikari SR Garg CC, et al. Catastrophic payments for health care in Asia. Health Econ. 2007:16:1159-84.

9. Xu K, Evans DB, Kawabata K, Zeramdini R, Klavus J, Murray CJ. Household catastrophic health expenditure: a multicountry analysis. Lancet. 2003;362: 111-7.

10. Mutangadura G, Gauci A, Armah B, Woldermariam E, Ayalew D, Egu B. Health inequities in selected African countries: review of evidence and policy implications. Econ Comm Afr. 2007. http://www.afdb.org/fileadmin/ uploads/afdb/Documents/Knowledge/Conference_2007_anglais_21-part-V1.pdf. Accessed 6 Oct 2016.

11. Leive A. Coping with out-of-pocket health payments: empirical evidence from 15 African countries. Bull World Health Organ. 2008:86:849-56.

12. WHO. In: Etienne C, Asamoa-Baah A, Evans DB, editors. The world health report: health systems financing: the path to universal coverage. Geneva: World Health Organization; 2010.

13. Chuma J, Maina T, Ataguba J. Does the distribution of health care benefits in Kenya meet the principles of universal coverage? BMC Public Health. 2012;12:1

14. Mills A, Ataguba JE, Akazili J, Borghi J, Garshong B, Makawia S, et al. Equity in financing and use of health care in Ghana, South Africa, and Tanzania: implications for paths to universal coverage. Lancet Lond Engl. 2012;380: 126-33.

15. Verguet S, Memirie ST, Norheim OF. Assessing the burden of medical impoverishment by cause: a systematic breakdown by disease in Ethiopia. BMC Med. 2016;14 https://doi.org/10.1186/s12916-016-0697-0.

16. Akinkugbe $\mathrm{O}$, Chama-Chiliba CM, Tlotlego N. Health financing and catastrophic payments for health care: evidence from household-level survey data in Botswana and Lesotho. Afr Dev Rev-Rev Afr Dev. 2012;24:358-70.

17. Kutzin J, et al. Health financing policy: a guide for decision-makers. Health Financ Policy Pap Cph WHO Reg Off Eur. 2008;24. http://www.who.int/ pmnch/topics/economics/healthfinancingpolicy/en/. Accessed 18 Apr 2016.

18. Khan KS, Kunz R, Kleijnen J, Antes G. Five steps to conducting a systematic review. J R Soc Med. 2003;96:118-21.

19. Gribble J, Haffey J. Reproductive health in sub-Saharan Africa. Population Reference Bureau.Policy brief. 2008. https://www.prb.org/ reproductivehealthafrica/.

20. Burgert-Brucker CR, Yourkavitch J, Assaf S, Delgado S. Geographic variation in key indicators of maternal and child health across 27 countries in Sub-Saharan Africa. DHS Spatial Analysis Reports No. 12. Rockv Md USA ICF Int. 2015.

21. Welch VA, Petticrew M, O'Neill J, Waters E, Armstrong R, Bhutta ZA, et al. Health equity: evidence synthesis and knowledge translation methods. Syst Rev. 2013;2:43.

22. Welch $V$, Tugwell P, Petticrew M, de Montigny J, Ueffing E, Kristjansson B, et al. How effects on health equity are assessed in systematic reviews of interventions. In: The Cochrane Collaboration, editor. Cochrane Database of Systematic Reviews. Chichester: John Wiley \& Sons, Ltd; 2010. doi:https://doi. org/10.1002/14651858.MR000028.pub2.

23. Tanimura T, Jaramillo E, Weil D, Raviglione M, Lönnroth K. Financial burden for tuberculosis patients in low- and middle-income countries: a systematic review. Eur Respir J. 2014;43:1763-75.

24. Alam K, Mahal A. Economic impacts of health shocks on households in low and middle income countries: a review of the literature. Glob Health. $2014 ; 10: 21$

25. Jaspers L, Colpani V, Chaker L, van der Lee SJ, Muka T, Imo D, et al. The global impact of non-communicable diseases on households and impoverishment: a systematic review. Eur J Epidemiol. 2015;30:163-88.

26. Russell S. The economic burden of illness for households in developing countries: a review of studies focusing on malaria, tuberculosis, and human 
immunodeficiency virus/acquired immunodeficiency syndrome. Am J Trop Med Hyg. 2004;71(2 suppl):147-55.

27. Goryakin $Y$, Suhrcke M. The prevalence and determinants of catastrophic health expenditures attributable to non-communicable diseases in low- and middle-income countries: a methodological commentary. Int J Equity Health. 2014;13 https://doi.org/10.1186/s12939-014-0107-1.

28. Kankeu HT, Saksena P, Xu K, Evans DB. The financial burden from noncommunicable diseases in low- and middle-income countries: a literature review. Health Res Policy Syst. 2013;11:31.

29. Peters M, Godfrey C, Mclnerney P, Soares C, Khalil H, Parker D. The Joanna Briggs Institute Reviewers' Manual 2015: Methodology for JBI Scoping Reviews. 2015. https://espace.library.uq.edu.au/view/UQ:371443. Accessed 22 May 2018.

30. Sene LM, Cisse M. Catastrophic out-of-pocket payments for health and poverty nexus: evidence from Senegal. Int J Health Econ Manag. 2015;15: 307-28

31. Arksey H, O'Malley L. Scoping studies: towards a methodological framework. Int J Soc Res Methodol. 2005;8:19-32.

32. Levac D, Colquhoun $\mathrm{H}, \mathrm{O}$ 'Brien KK. Scoping studies: advancing the methodology. Implement Sci. 2010;5 https://doi.org/10.1186/1748-5908-5-69.

33. Shamseer L, Moher D, Clarke M, Ghersi D, Liberati A, Petticrew M, et al. Preferred reporting items for systematic review and meta-analysis protocols (PRISMA-P) 2015: elaboration and explanation. BMJ. 2015;349(jan02 1):g7647.

34. Wardle J, Steel A. Systematic reviews in integrative medicine: a clinician's guide to publication. Adv Integr Med. 2015;2:103-9.

35. Wagstaff A, van Doorslaer E. Catastrophe and impoverishment in paying for health care: with applications to Vietnam 1993-1998. Health Econ. 2003;12: 921-33.

36. Ichoku HE, Fonta W, Onwujekwe O. Incidence and intensity of catastrophic healthcare financing and impoverishment due to out-of-pocket payments in southeast Nigeria. J Insur Risk Manag. 2009;4:47-59.

37. Mchenga M, Chirwa GC, Chiwaula LS. Impoverishing effects of catastrophic health expenditures in Malawi. Int J Equity Health. 2017;16 https://doi.org/ 10.1186/s12939-017-0515-0.

38. Onwujekwe OE, Ibe O, Torpey K, Dada S, Uzochukwu B, Sanwo O. Examining geographic and socio-economic differences in outpatient and inpatient consumer expenditures for treating HIV/AIDS in Nigeria. J Int AIDS Soc. 2016;19:20588.

39. Ilunga-Ilunga F, Levêque A, Laokri S, Dramaix M. Incidence of catastrophic health expenditures for households: an example of medical attention for the treatment of severe childhood malaria in Kinshasa reference hospitals, Democratic Republic of Congo. J Infect Public Health. 2015;8:136-44.

40. Laokri S, Dramaix-Wilmet M, Kassa F, Anagonou S, Dujardin B. Assessing the economic burden of illness for tuberculosis patients in Benin: determinants and consequences of catastrophic health expenditures and inequities. Tropical Med Int Health. 2014;19:1249-58.

41. Ichoku HE, Fonta WM. Catastrophic healthcare financing and poverty: empirical evidence from Nigeria. J Soc Econ Dev. 2009;11:1-16.

42. Ataguba JE-O. Reassessing catastrophic health-care payments with a Nigerian case study. Health Econ Policy Law. 2012;7:309-26.

43. Adisa O. Investigating determinants of catastrophic health spending among poorly insured elderly households in urban Nigeria. Int J Equity Health. 2015;14:79.

44. Su TT, Kouyaté B, Flessa S. Catastrophic household expenditure for health care in a low-income society: a study from Nouna District, Burkina Faso. Bull World Health Organ. 2006;84:21-7.

45. Dyer SJ, Sherwood K, Mclntyre D, Ataguba JE. Catastrophic payment for assisted reproduction techniques with conventional ovarian stimulation in the public health sector of South Africa: frequency and coping strategies. Hum Reprod. 2013;28:2755-64.

46. Ukwaja KN, Alobu I, Lgwenyi C, Hopewell PC. The high cost of free tuberculosis services: patient and household costs associated with tuberculosis care in Ebonyi State, Nigeria. PloS One. 2013;8:e73134.

47. Xu K, Evans DB, Kadama P, Nabyonga J, Ogwal PO, Nabukhonzo P, et al. Understanding the impact of eliminating user fees: utilization and catastrophic health expenditures in Uganda. Soc Sci Med 1982. 2006;62:866-76.

48. Xu K, James C, Carrin G, Muchiri S. An empirical model of access to health care, health care expenditure and impoverishment in Kenya: learning from past reforms and lessons for the future. WHO. 2006. http://www.who.int/ health_financing/documents/cov-dp_06_3_access_kenya/en/.
49. Masiye F, Kaonga O, Kirigia JM. Does user fee removal policy provide financial protection from catastrophic health care payments? Evidence from Zambia. PloS One. 2016;11:e0146508.

50. Ukwaja KN, Alobu I, Abimbola S, Hopewell PC. Household catastrophic payments for tuberculosis care in Nigeria: incidence, determinants, and policy implications for universal health coverage. Infect Dis Poverty. 2013;2:21.

51. Brinda EM, Andres RA, Enemark U. Correlates of out-of-pocket and catastrophic health expenditures in Tanzania: results from a national household survey. BMC Int Health Hum Rights. 2014;14:5.

52. Barasa EW, Maina T, Ravishankar N. Assessing the impoverishing effects, and factors associated with the incidence of catastrophic health care payments in Kenya. Int J Equity Health. 2017;16 https://doi.org/10.1186/s12939-017-0526-X.

53. Buigut S, Ettarh R, Amendah DD. Catastrophic health expenditure and its determinants in Kenya slum communities. Int J Equity Health. 2015;14 https://doi.org/10.1186/s12939-015-0168-9.

54. Beaulière A, Touré $S$, Alexandre $P-K$, Koné $K$, Pouhé $A$, Kouadio B, et al. The financial burden of morbidity in HIV-infected adults on antiretroviral therapy in Côte d'Ivoire. PLoS One. 2010;5:e11213.

55. Arsenault C, Fournier P, Philibert A, Sissoko K, Coulibaly A, Tourigny C, et al. Emergency obstetric care in Mali: catastrophic spending and its impoverishing effects on households. Bull World Health Organ. 2013;91:207-16.

56. Cleary S, Birch S, Chimbindi N, Silal S, Mclntyre D. Investigating the affordability of key health services in South Africa. Soc Sci Med 1982. 2013;80:37-46.

57. Kwesiga B, Zikusooka CM, Ataguba JE. Assessing catastrophic and impoverishing effects of health care payments in Uganda. BMC Health Serv Res. 2015;15:30.

58. Wang Q, Brenner S, Kalmus O, Banda HT, De Allegri M. The economic burden of chronic non-communicable diseases in rural Malawi: an observational study. BMC Health Serv Res. 2016;16:457.

59. Chuma J, Maina T. Catastrophic health care spending and impoverishment in Kenya. BMC Health Serv Res. 2012;12:413.

60. Niëns LM, Cameron A, Van de Poel E, Ewen M, Brouwer WBF, Laing R. Quantifying the impoverishing effects of purchasing medicines: a crosscountry comparison of the affordability of medicines in the developing world. PLoS Med. 2010;7:e1000333.

61. Onwujekwe O, Dike N, Chukwuka C, Uzochukwu B, Onyedum C, Onoka C, et al. Examining catastrophic costs and benefit incidence of subsidized antiretroviral treatment (ART) programme in south-east Nigeria. Health Policy Amst Neth. 2009;90:223-9.

62. Tomini SM, Packard TG, Tomini F. Catastrophic and impoverishing effects of out-ofpocket payments for health care in Albania: evidence from Albania living standards measurement surveys 2002, 2005 and 2008. Health Policy Plan. 2013;28:419-28.

63. Onwujekwe $\mathrm{O}$, Hanson K, Uzochukwu B. Examining inequities in incidence of catastrophic health expenditures on different healthcare services and health facilities in Nigeria. PLoS One. 2012;7:e40811.

64. Akazili J, McIntyre D, Kanmiki EW, Gyapong J, Oduro A, Sankoh O, et al. Assessing the catastrophic effects of out-of-pocket healthcare payments prior to the uptake of a nationwide health insurance scheme in Ghana. Glob Health Action. 2017;10:1289735.

65. Onwujekwe O, Hanson K, Uzochukwu B, Ichoku H, Ike E, Onwughalu B. Are malaria treatment expenditures catastrophic to different socio-economic and geographic groups and how do they cope with payment? A study in southeast Nigeria. Tropical Med Int Health. 2010;15:18-25.

66. Dorjdagva J, Batbaatar E, Svensson M, Dorjsuren B, Kauhanen J. Catastrophic health expenditure and impoverishment in Mongolia. Int J Equity Health. 2016;15 https://doi.org/10.1186/s12939-016-0395-8.

67. Rashad A, Sharaf M. Catastrophic economic consequences of healthcare payments: effects on poverty estimates in Egypt, Jordan, and Palestine. Economies. 2015;3:216-34.

68. Castillo-Riquelme M, Mclntyre D, Barnes K. Household burden of malaria in South Africa and Mozambique: is there a catastrophic impact? Tropical Med Int Health. 2008;13:108-22.

69. Mondal S, Kanjilal B, Peters DH, Lucas H. Catastrophic out-of-pocket payment for health care and its impact on households: experience from West Bengal, India. . Future Health Syst Innov Equity. 2010. http://www. chronicpoverty.org/uploads/publication_files/mondal_et_al_health.pdf. Accessed 1 Jun 2016.

70. Counts CJ, Skordis-Worrall J. Recognizing the importance of chronic disease in driving healthcare expenditure in Tanzania: analysis of panel data from 1991 to 2010. Health Policy Plan. 2016;31:434-43. 
71. Okoronkwo IL, Ekpemiro JN, Okwor EU, Okpala PU, Adeyemo FO. Economic burden and catastrophic cost among people living with type2 diabetes mellitus attending a tertiary health institution in south-east zone, Nigeria. BMC Res Notes. 2015:8:527.

72. Ughasoro MD, Onwujekwe OE, Ojinnaka NC. Economic cost of treatment of childhood epilepsy in Enugu, Southeast Nigeria. Int J Technol Assess Health Care. 2014;30:469-74.

73. Van Minh H, Kim Phuong NT, Saksena P, James CD, Xu K. Financial burden of household out-of pocket health expenditure in Viet Nam: findings from the National Living Standard Survey 2002-2010. Soc Sci Med. 2013;96:258-63.

74. Arsenijevic J, Pavlova M, Groot W. Measuring the catastrophic and impoverishing effect of household health care spending in Serbia. Soc Sci Med 1982. 2013;78:17-25.

Ready to submit your research? Choose BMC and benefit from:

- fast, convenient online submission

- thorough peer review by experienced researchers in your field

- rapid publication on acceptance

- support for research data, including large and complex data types

- gold Open Access which fosters wider collaboration and increased citations

- maximum visibility for your research: over $100 \mathrm{M}$ website views per year

At $\mathrm{BMC}$, research is always in progress.

Learn more biomedcentral.com/submissions 